\title{
The effect of institutional investors' distraction on firms' corporate social responsibility engagement: evidence from China
}

\begin{abstract}
To investigate the impact of institutional investors on firms' corporate social responsibility (CSR) engagement while controlling for possible endogeneity concerns, we study how Chinese listed firms adjust their CSR decisions when their institutional investors are distracted by exogenous attention-grabbing events and thus are inattentive. With a sample of Chinese listed firms from 2009 to 2017, we find a significant and robust negative relationship between institutional investor inattention and firms' CSR engagement. This negative relationship is more pronounced for firms with more principal-agent problems and/or weaker corporate governances and is more attributable to the inattention of institutional investors with more monitoring incentives. These findings suggest that managers are less motivated to engage in CSR when they are less monitored by institutional investors, indicating that CSR is beneficial to shareholders of Chinese listed firms. Our findings also indicate that the positive impact of institutional investors on CSR may be constrained by their limited attention.
\end{abstract}

Keywords: Corporate social responsibility; Institutional investors; Limited attention; Principal-agent problem; China 


\section{Introduction}

In recent decades, corporate social responsibility (CSR) engagement has become an important business practice worldwide. However, there is still an intense debate on whether CSR is beneficial to shareholder wealth. One stream of literature believes that CSR is initiated by managers' self-interest behaviors caused by agency problems (Tirole 2001; Benabou and Tirole 2010; Barnea and Rubin 2010; Martinez-Ferrero and Garcia-Sanchez 2015; Cheng et al. 2016a) and therefore, is harmful to shareholder wealth. The other stream of literature argues that CSR helps to create firm value for shareholders by mitigating firm risk (Ye and Zhang 2011; Gong et al. 2018), reducing information asymmetry (Martinez-Ferrero et al. 2018; Reverte 2016; Cui et al. 2018), improving board independence (Fernandez-Gago et al. 2016), generating moral capital among stakeholders (Lins et al. 2017) and gaining consumer support (Tian et al. 2011; Elfenbein et al. 2012; Servaes and Tamayo 2013).

One way to enter this debate is to investigate the impact of institutional investors on CSR engagement. As important shareholders, institutional investors have both the incentives and the power to affect firms' CSR decisions (Aggarwal et al. 2011; Dyck et al. 2019). Naturally, institutional investors would urge managers to engage more (less) in CSR if CSR is beneficial (harmful) to shareholder wealth. However, prior studies regarding the impact of institutional investors on CSR have reached mixed results (Choi et al. 2013; Petersen and Vredenburg 2009; Harjoto and Jo 2011; Dyck et al. 2019) ${ }^{1}$. Also, most prior studies investigate the impact of institutional investors on CSR through

\footnotetext{
1 Additionally, see Faller and Knyphausen-Aufsess (2018) for a literature review regarding the impact of institutional ownership on CSR.
} 
the perspective of institutional ownership, assuming that firms' institutional ownership, which is the percentage of firm shares owned by institutional investors such as mutual funds, banks, insurance companies, etc., is an appropriate proxy for institutional investors' monitoring intensity, i.e., the effort and time which institutional investors spend on monitoring firms as external monitors. However, there are endogeneity concerns about the relationship between institutional ownership and corporate actions (Boone and White 2015). It is not clear whether institutional ownership induces changes in CSR performance or instead migrates toward firms with better CSR performance.

This study aims to provide new empirical evidence regarding the impact of institutional investors on CSR with a sample of listed firms in China, the largest emerging market in the world. To address the endogeneity concern caused by the possible two-way causality between institutional ownership and firms' CSR engagement, we investigate how managers of Chinese listed firms adjust their CSR decisions when their institutional investors are distracted by exogenous attentiongrabbing events and are therefore inattentive to them.

Attention is a scarce cognitive resource (Kahneman 1973) and has been documented to influence the decisions of both individual investors (Barber and Odean 2008; Da et al. 2011; Da et al. 2014) and institutional investors ( $\mathrm{Lu}$ et al. 2016; Kacperczyk et al. 2016; Ben-Rephael et al. 2017; Schmidt 2019). The monitoring capacity of institutional investors is scarce as a result of their limited attention (Kempf et al. 2017) ${ }^{2}$. When institutional investors pay more attention to certain stocks in their

\footnotetext{
2 According to Kempf et al. 2017, the Investor Responsibility Research Center Institute (IRRC 2011) in America conducted a large-scale survey in 2011 and stated that "three-fourths of institutions report that time is the most 
portfolios, they have to simultaneously pay less attention to and thus reduce their monitoring intensity at others. We borrow the example in Kempf et al. (2017) to illustrate this idea more explicitly. Consider institutional investor $j$ who holds two stocks, firm $i$ and the other firm belonging to a different industry which we call "banks." Suppose now that there is an attention-grabbing event in the banking industry; for instance, a banking crisis that sends prices of bank stocks falling. Assuming limited attention, institutional investor $j$ rationally shifts attention towards banks and away from firm $i$. As a result, monitoring intensity at firm $i$ decreases, and the management of firm $i$ has more room to pursue private benefits. Since firm $i$ is not from the banking industry, the reduction in monitoring intensity at firm $i$ is exogenous.

Therefore, by observing how managers of Chinese listed firms adjust their CSR decisions to respond to the exogenous variation of institutional investors' monitoring intensity, we can establish the causality between firms' institutional investors and their CSR engagements without the concern of endogeneity issues. Specifically, a positive relationship between institutional investor inattention and CSR indicates that managers invest more in CSR when they are less monitored, supporting the notion that CSR is beneficial to managers instead of shareholders. In contrast, a negative relationship between institutional investor inattention and CSR indicates that managers invest less in CSR when they are less urged by institutional investors to do so, supporting the notion that CSR is beneficial to shareholders, including institutional investors.

To empirically study the abovementioned predictions, we collect a sample of common impediment to engagement [with corporations], while staffing considerations rank second.” 
Chinese listed firms from 2009 to 2017 . We measure firms' CSR engagement with their CSR scores issued by the Running and Loving Consulting for Common Welfare Co.Ltd (RKS for short). ${ }^{3}$ RKS is an independent third-party rating agency that follows the framework of the U.S. social investment rating agency Kinder, Lydenberg, Domini \& Co., Inc. (KLD). Every year, RKS evaluates CSR activities of Chinese public firms and assigns CSR scores to them based on their self-disclosed CSR reports. This evaluation system contains about 70 indicators that refer to the standards of the Global Reporting Initiative (GRI3.0) and ISO26000 (Guidance on Social Responsibility) but are adapted to China-specific CSR elements. The validity of RKS CSR scores was verified by Marquis and Qian (2014). RKS CSR scores are commonly used in prior studies on CSR activities in China (Marquis and Qian 2014; Lau et al. 2016; Gong et al. 2018; Zhang et al. 2018).

Meanwhile, we proxy for firm-level institutional investor inattention following Kempf et al. (2017). Our empirical results show that institutional investor inattention is significantly and negatively related to CSR after controlling for ownership structure, board structure, and other firm characteristics. This negative relationship is robust when we use alternative CSR proxies, when firm fixed effects are included in order to address the concern of omitted variables and when inattention proxies are one or two quarters lagged. Additionally, we find that institutional investors visit firms less when they are more inattentive to these firms, suggesting that they indeed loosen their monitoring intensity at firms when they are distracted. Therefore, the negative relationship

\footnotetext{
${ }^{3}$ http://www.rksratings.cn/.
} 
indicates that managers invest less in CSR when they are less monitored and thus less motivated to maximize shareholder wealth, supporting the notion that CSR is beneficial to shareholders of Chinese listed firms and that principal-agent conflicts between managers and shareholders, including institutional investors, contribute to the abovementioned negative relationship ${ }^{4}$.

Consistent with this argument, we find that the negative relationship between institutional investor inattention and CSR exists only in firms with relatively high expense ratios $^{5}$, low managerial ownership, low internal control quality, and low analyst coverage, i.e., firms with larger principal-agent costs or weaker corporate governance mechanisms that mitigate principal-agent problems. Also, the negative relationship is more attributable to the inattention of institutional investors with more monitoring incentives, that is, institutional investors with influential share fractions and/or longterm investment horizons (Aggarwal et al. 2011; Sandberg 2013) and dedicated institutional investors and quasi-indexers that are documented by prior studies as active market monitors (Appel et al. 2016; Borochin and Yang 2017).

We may make several contributions to the literature. First, we enrich the literature on the ongoing debate on whether CSR engagement is initiated by managers' selfinterested behaviors or is helpful in creating firm value for shareholders (Tirole 2001; Lins et al. 2017). We find that managers reduce CSR engagement when they are paid less attention and are thus less monitored by institutional investors. This effect is more

\footnotetext{
4 There is a rich literature documenting that agent problems are rampant in China (Allen et al., 2005; Jiang et al., 2010; He and Luo 2018).

5 As discussed later, the expense ratio, which is the operating expenses scaled by annual sales, is widely used to measure firms' agency costs caused by principal-agent problems (Ang et al. 2000; Fauver and Fuerst 2006; Jiang et al. 2015).
} 
pronounced for firms with more serious principal-agent problems and is more attributable to the inattention of institutional investors with more monitoring incentives. These findings suggest that shareholders of Chinese listed firms such as institutional investors demand CSR engagement, which in turn indicates that CSR is beneficial to shareholders for Chinese listed firms. Our findings are consistent with Wang and Li (2016), who show that CSR initiators in China have higher market valuations than matched CSR non-initiators, and Gong et al. (2018), who document that high CSR performance lowers corporate bond costs.

Second, we extend the literature on limited attention in behavioral finance. Although investor attention is found to be influential on information dissemination and asset pricing by a rich stream of literature, the study on its impact on corporate decisions is relatively limited (Baker and Wurgler 2013; Kempf et al. 2017). While Kempf et al. (2017) study the impact of institutional investor inattention on corporate operating actions such as acquisitions and CEO stock option grants, we investigate its impact on managers' CSR engagement, which is discretionary for most Chinese firms (Yin and Zhang 2012) and is not directly related to firms' operating performance. Compared to routine daily operation decisions, managers have more discretion to engage in CSR activities and thus are more likely to adjust CSR decisions in responding to the variation in their institutional investors' monitoring. Similar to Kempf et al. (2017), the negative relationship between institutional investor inattention and CSR in our study suggests that managers tend to maximize their own benefits instead of shareholder wealth when their institutional investors temporarily supply sub-optimal monitoring capacity as a 
result of exogenous attention-grabbing events. Specifically, our study suggests that the potential positive impact of institutional investors on CSR engagement might be constrained by their limited attention.

Third, we enrich the literature regarding the impact of institutional investors on CSR by providing new empirical evidence for listed firms in China, the largest emerging market in the world, while addressing the possible endogeneity concerns between institutional ownership and CSR. Among others, Lockett et al. (2006) call for more CSR studies in emerging markets where institutional background, culture, moral standards, and CSR awareness are quite different from those in developed markets where CSR studies have been primarily conducted. By extending the extant research to the context of China, we provide new insights into the relationship between institutional investors and CSR in emerging markets. Meanwhile, most prior studies illustrate the impact of institutional investors on CSR by showing the relationship between institutional ownership and CSR. However, this paradigm suffers from endogeneity concerns regarding a possible two-way causality. By studying how firms adjust CSR decisions when their institutional investors are distracted by exogenous attentiongrabbing events, our study is free from endogeneity concerns and thus offers meaningful insights for future studies in this field.

The remainder of our study is organized as follows. Section 2 describes the hypothesis development. Section 3 defines variable definitions and specifies empirical models. Section 4 reports summary statistics, Pearson correlation analysis, and regression results. Section 5 concludes the paper. 


\section{Hypothesis development}

After the 2008 melamine contamination incident, both consumers and investors showed a high level of awareness and trust in CSR (Wang et al. 2011) and valued firms with good CSR records (Tian et al. 2011). For Chinese public firms, investors offer higher market valuations for CSR initiators than for matched non-initiators (Wang and Li 2016). Additionally, Chinese listed firms with higher CSR disclosure quality are associated with lower debt costs (Gong et al. 2018). In short, good CSR practices are helpful for increasing long-term firm value and shareholder wealth of Chinese public firms. Hence, institutional investors in the China A-share market may have a positive attitude regarding CSR engagement.

By contrast, managers of Chinese public firms do not have as much incentive as do institutional investors to engage in CSR activities. Though growing, the sense of social responsibility is still relatively weak in China compared to western developed countries (Yin and Zhang 2012) ${ }^{6}$. Hence, managers would not obtain as many private benefits such as good reputation from firms' engagement as do their peers in western countries. Also, managers would not be punished or condemned if they do not make good CSR practices since it is not common for every Chinese public firm to engage in $\mathrm{CSR}^{7}$. Managers of Chinese firms do not have personal values that make them believe that CSR is important, either (Shafer et al. 2007).

In summary, managers of Chinese firms are not likely to initiate CSR activities for

\footnotetext{
${ }^{6}$ According to a survey reported in the China Sustainable Investment Review 2019, 89\% of the respondents said that they are not familiar with environmental, social and governance (ESG) investment, and $44 \%$ of them have never heard about "green investment", "social responsibility investment" or "ESG". See http://f.sinaimg.cn/client/ebe07d0f/20191205/ChinaSIF2019.pdf

7 For instance, approximately $43 \%$ of Chinese listed firms do not even disclose CSR reports in our sample period.
} 
self-interested purposes. Meanwhile, there are severe principal-agent problems in Chinses public firms. Therefore, managers are not motivated to make good CSR practices to create firm value for shareholders unless they are well monitored by institutional investors among other corporate mechanisms.

Naturally, to monitor managers' CSR engagement, institutional investors should carefully pay attention to managers. However, as a scarce cognitive resource, attention is not unlimited even for institutional investors (Ben-Rephael et al. 2017; Lu et al. 2016). They must allocate their limited attention across hundreds of stocks in their portfolios. When institutional investors are distracted by exogenous attention-grabbing events, they loosen their monitoring intensity on managers as a result of their limited attention (Kempf et al. 2017). Aware of being less monitored, managers are more likely to maximize their private benefits than to create firm value for shareholders through CSR engagement. Thus, managers will engage less in CSR when they are paid to less attention and are thus less monitored by institutional investors. Our hypothesis $\mathrm{H} 1$ is thus stated as follows:

\section{H1: Institutional investor inattention is significantly and negatively related to}

\section{firms' CSR engagement.}

To test the robustness of the negative relationship between institutional investor inattention and CSR, we then investigate the cross-sectional differences in the negative relationship. We argue that managers reduce CSR engagement when they are paid to less attention by institutional investors and hence are less motivated to create firm value through CSR. Thus, the negative relationship is attributable to the principal-agent 
problem between managers and shareholders, including institutional investors. If so, the negative relationship should be more pronounced for firms with more serious principal-agent problems or weaker corporate governance mechanisms that mitigate principal-agent problems.

Specifically, we expect that this relationship is more pronounced for firms with higher expense ratios, less managerial ownership, weaker internal controls, and less analyst coverage. According to Ang et al. (2000), excessive expense on perks and other nonessentials is reflected in the operating expenses. Therefore, the expense ratio, which is operating expense scaled by annual sales, is a measure of firm-level direct agency costs including shirking and excessive perquisite consumption by managers. Higher operating expense to sales ratios indicates more excessive perquisite consumption and thus higher agency costs. The expense ratio is used to measure agency costs caused by principal-agent problems in prior studies (Fauver and Fuerst 2006; Jiang et al. 2015). In addition, managerial ownership is designed to align the interests of managers and shareholders and hence helps mitigate the principal-agent problem, while internal controls and analyst coverage are documented by a large body of literature as internal and external governance mechanisms that mitigate agency problems (Goh and Li 2011; Adhikari 2016). Therefore, our hypothesis H2 is stated as follows:

H2: The negative relationship between institutional investor inattention and CSR is more pronounced for firms with higher expense ratios, less managerial ownership, weaker internal controls, and less analyst coverage.

Similarly, if the negative relationship between institutional investor inattention and 
CSR is caused by the principal-agent problem, the inattention of institutional investors with more monitoring incentives would cause a larger decrease in monitoring intensity and thus a larger negative impact on CSR. To study this prediction, we categorize institutional investors into different groups with different potential monitoring incentives and investigate whether institutional investors in different groups exhibit different impacts on firms' CSR engagement.

First, we group institutional investors according to their institution types. Institutional investors in China's A-share market are classified into ten major institution types $^{8}$. The fraction of ownership and investment horizons differ considerably across institution types ${ }^{9}$. Aggarwal et al. (2011) show that both the monitoring incentives and the monitoring power of institutional investors are largely determined by their fractions of firm shares. Therefore, naturally, the inattention of institutional investors with larger ownership is likely to have a larger impact on firms' CSR engagement. Meanwhile, institutional investors with longer investment horizons are associated with more monitoring incentives (Appel et al. 2016). They are more likely to promote firms' CSR engagement to minimize external costs caused by poor social or environmental performances (Cox et al. 2004; Sandberg 2013). The review in Faller \& KnyphausenAufsess (2018) also concludes that long-term institutional investors show a more positive attitude regarding CSR than do short-term institutional investors. Hence, long-

\footnotetext{
${ }^{8}$ Namely, these types are insurance companies, public mutual funds, the national social security fund, exchangetraded funds, overseas institutional investors, corporate annuity plans, banks, trust companies, brokerage firms, and private investment funds.

${ }_{9}$ As discussed later in section 4.4.1, insurance companies, mutual funds, and the national security fund are the three largest institutional investors in the Chinese A-share market. The institutional ownership of other institutional investors is relatively minor.
} 
term institutional investors are more likely to urge managers to engage in CSR activities. Correspondingly, the distraction of long-term institutional investors is likely to show a larger impact on managers' CSR engagement. Therefore, we present our hypothesis H3a as follows:

\section{H3a: The negative relationship between institutional investor inattention and}

CSR is more attributable to institutions with influential ownership and/or long investment horizons.

Second, we identify institutional investors' monitoring incentives by their portfolio holdings and investment styles following Bushee (1998) and Bushee and Noe (2000). Bushee (1998) and Bushee and Noe (2000) classify institutional investors into dedicated institutional investors, transient institutional investors, and quasi-indexers based on their portfolio concentrations, portfolio turnover, and trading strategies. Dedicated institutional investors, which are associated with high portfolio concentration, low portfolio turnover and low trading sensitivity to current earnings, have strong incentives and power to actively engage in corporate governance activities to benefit from the increase in long-term firm value (Borochin and Yang 2017). Quasiindexers usually own highly diversified portfolios and follow a buy-and-hold investment strategy. Quasi-indexers are also active corporate monitors because the improvement of corporate governance helps improve stock liquidity and reduce the transaction cost, which is vital for quasi-indexers' investment returns due to their passive investment strategy (Bird and Karolyi 2016). In contrast, transient institutional investors, which have high portfolio turnover and prefer short-term market benefits, 
show relatively weak interest in corporate governance (Boone and White 2015). Our hypothesis $\mathrm{H} 3 \mathrm{~b}$ is thus stated as follows:

H3b: The negative relationship between institutional investor inattention and CSR is more attributable to dedicated institutional investors and quasi-indexers.

\section{Research design}

\subsection{Data and sample selection}

We use a sample of Chinese listed firms from 2009 to 2017, as our CSR data are available since 2009. We obtain CSR data for Chinese listed firms from Running and Loving Consulting for Common Welfare Co. Ltd, or RKS for short. Since 2009, RKS has collected CSR data from CSR disclosure reports of Chinese listed firms and evaluated these reports with both scores and rates. We obtain data regarding the portfolios of institutional investors from Wind, a professional financial data provider in

China. Data regarding stock returns, firm financial information, ownership structure, board structure, and other firm characteristics are obtained from the China Stock Market \& Accounting Research database (CSMAR). After deleting firms in the financial industry and firms with missing control variables, we obtain a sample of 12,556 firmyear observations. To mitigate the impact of outliers, all continuous variables are winsorized at the $1 \%$ and $99 \%$ levels.

\subsection{Variables}

\subsubsection{CSR proxies}

Following prior studies on CSR in China (Marquis and Qian 2014; Lau et al. 2016; Gong et al. 2018; Zhang et al. 2018), we use RKS CSR scores to construct proxies for 
the CSR engagement of our sample firms. Since 2009, RKS annually reviews selfdisclosed CSR reports of Chinese public firms and evaluates their CSR activities with about 70 indicators. As mentioned in the introduction section, these indicators follow the framework of KLD and refer to the standards of GRI3.0 and ISO26000, but are adapted to China-specific CSR elements. These indicators were classified into three dimensions before 2011. The first dimension is "Macrocosm" with indicators about firms' CSR strategy, corporate governance, and stakeholder participation. The second dimension is "Content" with indicators about firms' economic performance, employment and human rights, environmental performances, fairness in operation, customer protection, and community participation and development. The third dimension is "Technique" with indicators about the content balance, comparability, innovativeness, creditability and transparency, normalization, availability and information communication efficiency of firms' CSR reports. Since 2011, the fourth dimension, "Industry", was added to RKS CSR scores. Criteria for rating CSR engagement in the "Industry" dimension varies across industries. For instance, RKS uses ecological environment and management indicators to evaluate CSR engagement for firms in the mining industry and construction waste discharge indicators for firms in the real estate industry. The RKS CSR score of firm $i$ in year $t$ (denoted as Score $_{i, t}$ ) is then formulated by aggregating the scores of these four dimensions. RKS CSR scores range from 0 to 100 . For the year 2009 and 2010, Macrocosm $\left(M_{i, t}\right)$, Content $\left(C_{i, t}\right)$ and Technique $\left(T_{i, t}\right)$ have a weight of $30 \%, 50 \%$, and $20 \%$, respectively. Thus, $M_{i, t}$ ranges from 0 to 30 , et cetera. Since 2011 , the weight is $30 \%$ for $M_{i, t}, 45 \%$ for $C_{i, t}, 15 \%$ for $T_{i, t}$, 
and $10 \%$ for industry $\left(I_{i, t}\right)$. By definition, a higher RKS score indicates more CSR engagement and better CSR performance.

RKS relies on self-disclosed CSR reports of Chinese public firms to grade their CSR engagement. Constituent stocks of the Shenzhen 100 Index and Shanghai Corporate Governance Index, firms in the finance industry and firms cross-listed on overseas stock exchanges are mandated to disclose annual CSR reports, while other firms are discretionary to disclose their CSR reports. We use both firms that are mandated to disclose CSR reports and firms that are discretionary to do so as sample firms. The former firms and the latter firms provide about $26 \%$ and $74 \%$ of observations in our sample, respectively. For the latter firms, on average, about 57\% (43\%) of them choose (choose not) to disclose CSR reports. Following Gong et al. (2018), we assign Score $_{i, t}, M_{i, t}, C_{i, t}, T_{i, t}$ and $I_{i, t}$ a value of zero if firm $i$ does not disclose a CSR report in year $t$.

\subsubsection{Institutional investor inattention}

We follow Kempf et al. (2017) and construct a firm-level institutional investor inattention proxy based on exogenous attention-distracting events, or extreme industry returns to be specific. The intuition behind this proxy is described as follows. Assume that institutional investor $j$ holds shares of two firms (denoted as Firm $i$ and Firm $f$ ) in two different industry sectors by the end of quarter $q$ - 1 . In quarter $q$, the industry sector to which Firm $f$ belongs has the highest or lowest return among all industry sectors. Thus, Firm $f$ experiences an extreme industry return and thus is attention-grabbing (Barber and Odean 2008). Institutional investor $j$ would be attracted by the extreme 
industry return and pay more attention to $\operatorname{Firm} f$, and simultaneously pay less attention to Firm $i$ due to his/her attention constraint. Thus, institutional investor $j$ reduce his/her monitoring intensity on firm $i$ because he/she is distracted by the attention-grabbing event of firm $f$. Since Firm $i$ and Firm $f$ are from different industries, the decrease in monitoring intensity on firm $i$ is reasonably assumed to be exogenous. The distraction effect of institutional investor $j$ on firm $i$ depends on the weight of firm $f$ in its stock portfolio and its ownership in firm $i$. The former indicates how important firm $f$ is to institutional investor $j$ and the latter indicates how influential institutional investor $j$ is to firm $i$. Based on this idea, an inattention score of investor $j$ to firm $i$ is computed. By aggregating inattention scores of all firm $i$ 's institutional investors with the model (1), we then obtain firm $i$ 's institutional investor inattention level in quarter $q\left(\operatorname{InAtt}_{i, q}\right)$.

$$
\operatorname{InAtt} t_{i, q}=\sum_{j \in n_{q-1}} \sum_{I N \neq I N_{i}} w_{i, j, q-1} * w_{j, q-1}^{I N} * I S_{q}^{I N}
$$

$j$ denotes institutional investor $j$ of firm $i$, and $n_{q-1}$ denotes the set of firm $i$ 's institutional investors by the end of quarter $q-1 . I S_{q}^{I N}$ is a dummy that equals 1 if the industry sector $I N$ has the highest or lowest return across all industry sectors in quarter $q$ and 0 otherwise. $w_{j, q-1}^{I N}$ is defined as the weight of industry $I N$ in institutional investor $j$ 's portfolio. $w_{i, j, q-1}$ is a weighting factor measuring how influential institutional investor $j$ is to firm $i$ in quarter $q-1$ and is calculated with the model (2).

$$
w_{i, j, q-1}=\frac{Q I O_{i, j, q-1}+Q P W_{i, j, q-1}}{\sum_{j \in n_{q-1}}\left(Q I O_{i, j, q-1}+Q P W_{i, j, q-1}\right)}(2)
$$

$I O_{i, j, q-1}$ is the percentage of firm $i$ 's shares held by institutional investor $j$, and $P W_{i, j, q-1}$ is the weight of firm $i$ in investor $j$ 's portfolio. We then sort $I O_{i, j, q-1}$ and $P W_{i, j, q-}$ ${ }_{1}$ into quintiles (denoted as $Q I O_{i, j, q-1}$ and $Q P W_{i, j, q-1}$ ) to minimize the impact of outliers 
and the measurement error following Kempf et al. (2017). We scale the sum of $Q I O_{i, j, q-}$ 1 and $Q P W_{i, j, q-1}$ by the denominator so that the sum of $w_{i, j, q-1}$ equals 1 . Finally, we aggregate $I n A t t i, q$ in a given year to obtain the firm-year institutional investor inattention $\left(\operatorname{InAtt} i_{i, t}\right)$.

It's reasonable to argue that $\operatorname{InAtt}_{i, q}$ is valid only if institutional investors engage in multiple industries and do not have the capacities to follow the industries in parallel, and the distraction is enduring for a long time period as well. We believe these requirements are satisfied in our study. There is a growing literature documenting that institutional investors suffer from limited attention (Lu et al. 2016; Kacperczyk et al. 2016; Ben-Rephael et al. 2017; Kempf et al. 2017). In our sample, on average, an institutional investor holds 76.54 stocks from 9.18 industries ${ }^{10}$. These figures support that institutional investors are indeed engaged in multiple industries. Besides, economic fundamentals underlying distraction events are complicated, and these events take time to unfold and to be understood. Even short but unanticipated events such as natural disasters, court rulings or new legislation may take time to fully understand the impact. Therefore, the distraction events can have a prolonged impact on monitoring capacity that would be relevant for managerial actions ${ }^{11}$.

Kempf et al. (2017) provide evidence that this inattention proxy properly measures firms' institutional monitoring intensity by showing that it is significantly and negatively related to institutional investors' participation in firms' conference calls and

\footnotetext{
${ }^{10}$ We follow the industry classifications issued by the China Securities Regulatory Commission (CSRC) in 2012 and classify stocks into 19 industries.

${ }^{11}$ See section 2.2 in Kempf et al. (2017) for a detailed discussion on this.
} 
shareholder proposals. As discussed later in section 4.2.5, we find this proxy is significantly and negatively related to the frequency on which firms' institutional investors pay visits to them, indicating it's also valid for the Chinese context.

\subsubsection{Model specification}

Our baseline model is specified in the model (3):

$$
\operatorname{CSR}_{i, t}=\alpha+\beta_{1} \operatorname{InAtt}_{i, t}+\sum \text { Control }+\varepsilon_{i, t}
$$

$C S R_{i, t}$ is the proxy for firm $i$ 's CSR engagement, such as the total RKS CSR scores and the four sub-category scores in year $t$. InAtti,t is calculated with the model (2) following Kempf et al. (2017). ¿Control stands for the set of control variables. Following prior studies (Ferrell et al. 2016; Zhang et al. 2018), we control a set of variables related to firm characteristics, internal governance mechanisms, and external governance mechanisms. To be more specific, we first control for firm characteristics, including firm size $\left(\right.$ Size $\left._{i, t}\right)$, the book-to-market ratio $\left(B M_{i, t}\right)$, financial leverage $\left(\operatorname{Lev}_{i, t}\right)$, return on assets $\left(R O A_{i, t}\right)$, capital expenditure $\left(\operatorname{Capex}_{i, t}\right)$, analyst coverage $\left(A C_{i, t}\right)$ and the indicator of state-owned enterprises $\left(S O E_{i, t}\right)$. Second, we control for a set of ownership structure variables, including institutional ownership $\left(I O_{i, t}\right)$, managerial ownership $\left(M O_{i, t}\right)$, the share percentage of the largest shareholder $\left(T O P 1_{i, t}\right)$ and the ownership concentration of the top 5 shareholders $\left(H H I 5_{i, t}\right)$. Finally, we control for a set of board structure variables including board size $\left(B\right.$ Size $\left._{i, t}\right)$, board independence $\left(\right.$ BIndep $\left._{i, t}\right)$ and CEO duality $\left(\right.$ Duality $\left._{i, t}\right)$. Detailed definitions of all variables used in this study are provided in the Appendix.

\section{Empirical results}




\subsection{Summary statistics}

We summarize descriptive statistics regarding the main variables used in this study in Table 1. The mean of $\operatorname{InAtt}_{i, t}$ is 0.0574 and is smaller than that $(0.16)$ in Kempf et al. (2017). The reason for this difference is straightforward. The mean institutional ownership for sample firms in this study is $18.05 \%$, while that in Kempf et al. (2017) is approximately $43 \%$. Nevertheless, the standard deviation of $I n A t t_{i, t}$ is 0.0900 and is comparable to that (0.07) in Kempf et al. (2017). The mean of Score $e_{i, t}$ is 21.9686 and is quite close to that (19.47) in Gong et al. (2018). On average, macrocosm (M), content (C), technique $(T)$ and industry $(I)$ contribute 7.2992, 9.5719, 3.8109 and 1.0937 scores to Score $_{i, t}$, respectively. With respect to firm characteristics, the average book-to-market ratio $\left(B M_{i, t}\right)$, return on assets $\left(R O A_{i, t}\right)$ and financial leverage $\left(\operatorname{Lev}_{i, t}\right)$ are $0.9247,4.45 \%$ and $46.29 \%$, respectively. In total, $47.23 \%$ of sample firms are state-owned $\left(S O E_{i, t}\right)$. In addition, on average, managers hold $5.37 \%$ of firm shares $\left(M O_{i, t}\right)$, while the first top shareholder owns $35.26 \%$ of firm shares.

\section{$<$ Insert Table 1 about here $>$}

Panel A of Table 2 reports the Pearson correlations of the variables. Consistent with our hypothesis H1, Score $_{i, t}$ is negatively correlated with InAtt $t_{i t}$. The correlations between Score $_{i, t}$ and firm characteristics are also informative. For example, Score $_{i, t}$ is positively correlated with analyst coverage, institutional ownership, managerial ownership, and board independence and is negatively related to top 5 ownership concentration and board size. These correlations support that better internal or external corporate governance induces more CSR engagement for Chinese listed firms. 
Therefore, these correlations are consistent with our predictions that CSR is beneficial to shareholders for Chinese listed firms, and managers may reduce CSR engagement when they are less monitored by institutional investors and other governance mechanisms. In addition, as shown in Panel B, the correlation coefficients among control variables are generally low, and the variance inflation factors of all explanatory variables are far less than 10 , indicating that our results are free from collinearity problems.

\section{$<$ Insert Table 2 about here $>$}

\subsection{The impact of institutional investor inattention on CSR}

\subsubsection{Baseline regression results}

The regression results of the model (3) are reported in Table 3. Total RKS CSR scores $\left(\right.$ Score $\left._{i, t}\right)$, macrocosm scores $\left(M_{i, t}\right)$, content scores $\left(C_{i, t}\right)$, technique scores $\left(T_{i, t}\right)$ and industry scores $\left(I_{i, t}\right)$ are used as dependent variables in columns (1) to (5), respectively. Year and industry fixed effects are included in all regressions. T-statistics in parentheses are based on robust standard errors. For the convenience of interpretation, InAtt $t_{, t}$ is standardized to have a zero mean and unit variance in all regressions. As shown in column (1), InAtt $t_{i, t}$ is negatively related to Score $_{i, t}$ with a significance level of $5 \%$ (t-statistics=-1.99). The coefficient of $\operatorname{InAtt}_{i, t}(-0.554)$ indicates that a one-unit increase in $\operatorname{InAtt}_{i, t}$ would lead to a decrease of $\operatorname{Score}_{i, t}$ by 0.554 . Quite similar results are inferred when CSR scores in each subcategory (M, C, T, and I) are used as dependent variables. $M, C$, and $I$ are negatively related to Score $_{i, t}$ with a $5 \%$ significance level or higher. The coefficient of $T$ is also negative but is statistically insignificant. 
These findings indicate that the inattention of institutional investors affects CSR in a variety of aspects. Meanwhile, $I O_{i, t}$ is significantly and positively related to $\operatorname{Score}_{i, t}$ and the four subcategories of CSR scores. Overall, these findings suggest that although more institutional ownership could urge managers to invest more in CSR, managers reduce CSR engagement when institutional investors are inattentive to them, which is consistent with our hypothesis H1.

The relationships among Score $_{i, t}$ and control variables in Table 3 are similar to those shown in the correlation matrix in Table 2. Score $_{i, t}$ is higher for firms with more analyst coverage, less ownership of the largest shareholder, larger managerial ownership, and more board independence and for firms for which the CEO does not chair the board, i.e., firms that are associated with stronger internal or external governance. Along with the negative relationship between $\operatorname{InAtt}_{i, t}$ and $\operatorname{Score}_{i, t}$, it is concluded that for Chinese listed firms, managers are less motivated to engage in CSR activities when they are less monitored by institutional investors and other corporate governance mechanisms. In addition, Score $_{i, t}$ is higher for firms with larger sizes, higher book-to-market ratios, lower financial leverage, more capital expenditure and SOEs.

\section{$<$ Insert Table 3 about here $>$}

\subsubsection{Alternative CSR proxies}

To check the robustness of the relationship between $\operatorname{InAtt}_{i, t}$ and Score $_{i, t}$, we use alternative CSR proxies and repeat the regressions with the model (3). First, following Zhang et al. (2018), we alternatively measure CSR engagement with a dummy indicating whether a firm chooses to disclose CSR reports in a given year. To be more 
specific, we exclude from our sample firms that are mandated to disclose CSR reports and then define $D D i s_{i, t}$ as 1 if firm $i$ voluntarily discloses its CSR report in year $t$ and 0 otherwise. The mean of DDis $s_{i, t}$ is 0.5727 , which indicates that on average, approximately $43 \%$ of Chinese listed firms choose not to disclose CSR reports in our sample period.

We then run logit regressions on the model (3) with $D D i s_{i, t}$ as the dependent variable and report the regression results in column (1) of Table 4. InAtti,t is negatively related to DDis $s_{i, t}$ at a significance level of $5 \%$ (t-statistic=-2.33), suggesting that managers are more likely to choose not to disclose CSR reports when institutional investors are more inattentive to them. Compared with firms with good CSR performance, firms with poor CSR performance are naturally less likely to voluntarily disclose their CSR reports. Therefore, this finding supports the robustness of the negative relationship between institutional investor inattention and CSR engagement shown in Table 3.

We also alternatively measure CSR engagement with firms' CSR scores issued by an alternative financial media, i.e., the hexun.com (HX hereafter). HX is a leading internet financial media firm in China and began to issue CSR scores for Chinese listed firms in 2010. Similar to RKS CSR scores, HX CSR scores are also based on CSR disclosure reports of Chinese listed firms. Unlike RKS CSR scores, HX establishes five subcategories of CSR scores, including scores for shareholder responsibility, employee responsibility, customer responsibility, environmental responsibility, and social responsibility. We denote HX CSR scores and the five subcategories of CSR scores as 
HXScore $_{i, t}$, SHolder $_{i, t}$, Employee $_{i, t}$, Customer $_{i, t}$, Envir $_{i, t}$ and Social $i, t$, respectively. We then use them as dependent variables in the model (3) and report the regression results in columns (2) to (6) of Table 4. InAtt ${ }_{i, t}$ is negatively related to HXScore ${ }_{i, t}$, Employee $_{i, t}$, Customer $_{i, t}$ and Envir $_{i, t}$ with a 10\% or higher significance level. Both SHolder $_{i, t}$ and Social $_{i, t}$ are insignificantly related to InAtt $_{i, t}$. The results in columns (2) to (6) of Table 4 suggest that $\operatorname{InAtt}_{i, t}$ has a significant and negative impact on firms' overall CSR engagement and on a variety of CSR aspects. These findings again support the robustness of the negative relationship between institutional investor inattention and CSR engagement, as stated by hypothesis $\mathrm{H} 1$.

\section{$<$ Insert Table 4 about here $>$}

\subsubsection{The concern on omitted variables}

There is a rich body of literature on the factors of firms' CSR decisions. Although we add a set of common factors as control variables in our model, it is still possible that we omit important variables. To address this concern, we add firm fixed effects to the regressions. In addition, we use the first-order difference of RKS's CSR scores and the four sub-categories of scores as dependent variables of the model (3). We report these regression results in Table 5. As shown in Table 5, although a large number of control variables become insignificant, the coefficients of InAtt $t_{i, t}$ remain significantly negative in columns (1), (2) and (3). Larger institutional investor inattention causes a significantly greater decrease in macrocosm scores $(M)$, content scores $(C)$ and total CSR scores. Again, these findings suggest a robust negative relationship between institutional investor inattention and CSR engagement. 


\section{$<$ Insert Table 5 about here $>$}

\subsubsection{Lagged institutional investor inattention proxies}

In baseline model regressions, we regress firms' CSR proxies of year $t$ on their institutional investor inattention proxies of the same year. However, managers may take time to adjust their CSR decisions after they sense that they are less monitored. Therefore, the actual impact of institutional investor inattention may exhibit with time lags. Therefore, in this section, we lag our inattention proxies for one or two quarters and run the empirical tests again as robustness tests. That is, we study how firms' institutional investor inattention affects firms' CSR engagement in the future one or two quarters.

Specifically, for firm $i$, we calculate its institutional investor inattention proxies in quarter 4 of year $t-1$, and quarters 1,2 and 3 of year $t$. We then aggregate these four inattention proxies to obtain $\operatorname{InAtt} t_{i, t}^{q 1}$, the one quarter lagged institutional investor inattention proxy of firm $i$ in year $t$. We then replace $\operatorname{InAtt}_{i, t}$ with $\operatorname{InAtt}_{i, t}^{q 1}$ in the baseline model and run regressions again. Regression results are reported in Panel A of Table 6. $\operatorname{InAtt} t_{i, t}^{q 1}$ is significantly and negatively related to $\operatorname{Score}_{i, t}, M_{i, t}, C_{i, t}$ and $I_{i, t}$ just as is InAtt $t_{i, t}$ in Table 3. We reach quite similar findings when we lagged institutional investor inattention proxy with two quarters in Panel B of Table 6. These results support the robustness of our argument regarding the impact of institutional investor inattention on frims' CSR decisions.

\footnotetext{
$<$ Insert Table 6 about here >
}

\subsubsection{Institutional investor inattention and monitoring intensity}


Based on the findings of Kempf et al. (2017), we assume that institutional investors' inattention level is inversely related to their monitoring intensity. Therefore, we argue that the negative relationship between institutional investor inattention and CSR indicates that managers are less motivated to create firm value through CSR when they are less monitored by institutional investors. Our argument holds only if the abovementioned assumption holds. To test this assumption and therefore check the robustness of our argument, we investigate whether institutional investors loosen their monitoring intensity on firms when they are inattentive. Specifically, we study the impact of institutional investor inattention on the possibility and frequency at which firms are visited by their institutional investors. Recent studies show that site visits offer visitors such as institutional investors opportunities to meet managers privately and express their concerns (Han et al. 2018; Cheng et al. 2019). Therefore, if institutional investors loosen their monitoring intensity on firms when they are inattentive, they will visit these firms less.

To test this prediction empirically, we follow Han et al. (2018) and Cheng et al. (2019) to construct the determinant model of visits, which is shown in model (4).

$$
\text { Visit }_{i, t}=\alpha+\beta_{1} \text { InAtt }_{i, t}+\text { Control }+\varepsilon_{i, t}
$$

Visit $_{i, t}$ is proxied by either DVisit ${ }_{i, t}$ or $N V_{i s i t_{i, t} .}$ DVisit $t_{i, t}$ equals 1 if firm $i$ is visited at least once by institutional investors in year $t$ and equals 0 otherwise. NVisitit, is the natural logarithm of 1 plus the times that firm $i$ is visited by institutional investors in year $t$. Because only firms listed in the Shenzhen Stock Exchange (SZSE) in China are mandated to disclose site visit events, we use only SZSE firms as sample firms in the 
model $(4)^{12}$. The variable of interest in the model (4) is InAtti,t. We expect a significantly negative $\beta_{1}$, which indicates that institutional investors visit firms less and loosen their monitoring intensity when they are more inattentive. The other explanatory variables in the model (4) are borrowed from Han et al. (2018) and Cheng et al. (2019). DManu $u_{i, t}$ equals 1 if firm $i$ is in the manufacturing industry and 0 otherwise. DRate $e_{i, t}$ equals 1 if the information disclosure quality of firm $i$ is relatively poor and hence is rated as $\mathrm{C}$ or $\mathrm{D}$ by the SZSE and equals 0 otherwise. Ret $_{i, t}$ is the market-adjusted stock return of firm $i$ in year $t . A g e_{i, t}$ is the natural logarithm of years for which firm $i$ has been listed on the SZSE. MShare $e_{i, t}$ is the market share of firm $i$ in year $t$. NFirms $s_{i, t}$ is the natural logarithm of the total number of listed firms in the city where firm $i$ is headquartered, while GDPGrowth is $_{i}$ is the GDP growth of the city where firm $i$ is headquartered. All variables are defined in the appendix.

We report the regression results of the model (4) in Table 7. DVisiti,t is used as the dependent variable in column (1), and NVisit $t_{i, t}$ is used as the dependent variable in column (2). As expected, InAtt $t_{i, t}$ is negatively related to both $D V i s i t_{i, t}$ and NVisit $t_{i, t}$ with a significance level of 5\%, indicating that institutional investors visit firms less when they are more inattentive. These findings support our assumption that the inattention level of institutional investors is inversely related to their monitoring intensity. Therefore, these findings also support our argument that managers are less motivated to create firm value for shareholders through CSR when they are paid less attention and

\footnotetext{
12 There are two stock exchanges in China, that is, the Shanghai Stock Exchange (SSE) and the Shenzhen Stock Exchange. Firms listed on SSE are not required to disclose site visit events. Please see Cheng et al. (2016b), Han et al. (2018) and Cheng et al. (2019) for details regarding the institution background of site visits in the Chinese Ashare market.
} 
are less monitored.

\section{$<$ Insert Table 7 about here $>$}

\subsection{Sub-sample analyses based on firm characteristics}

As stated in the development of hypothesis $\mathrm{H} 2$, we expect the negative relationship between institutional investor inattention and CSR to be more pronounced for firms with more serious principal-agent problems. To test hypothesis $\mathrm{H} 2$, first, we investigate whether the abovementioned negative relationship is more pronounced for firms with high expense ratios and hence high agency costs (Ang et al. 2000). To do so, we divide our sample into two sub-samples. A firm-year observation is classified into the high agency cost sub-sample if its expense ratio is above the sample median in a given year; otherwise, it is classified into the sub-sample of low agency costs. We then re-estimate the model (3) with the two sub-samples. The regression results are reported in columns (1) and (2) in Panel A of Table 8. InAtti,t is negatively related to Score $_{i, t}$ in both columns (1) and (2) but is only statistically significant in column (1), where the sub-sample of high agency costs is used in the regressions. These findings indicate that the negative relationship between institutional investors exists only when a firm has relatively high agency costs, which is consistent with hypothesis $\mathrm{H} 2$.

Second, we investigate whether the negative relationship is more pronounced for firms with less managerial ownership. Both Cheng et al. (2016a) and Masulis and Reza (2015) argue that spending on CSR in the United States is due partly to agency problems by showing the reverse relationship between CSR and managerial ownership. Similarly, if the negative relationship between $\operatorname{InAtt}_{i, t}$ and Score $_{i, t}$ is caused by agency problems, 
managers holding more firm shares should be less affected by the decreased monitoring intensity of institutional investors and hence be less likely to reduce CSR engagement. To investigate this possibility empirically, we divided our sample into two sub-samples based on managerial ownership. A firm-year observation is classified into the subsample of high managerial ownership if its managerial ownership is above the sample median in a given year; otherwise, it is classified into the sub-sample of low managerial ownership. Regression results with these sub-samples are reported in columns (3) and (4) in Panel B of Table 8. InAtti,t is insignificantly and positively related to Score $_{i, t}$ for the sub-sample of high managerial ownership in column (3). In contrast, InAtti,t is negatively related to $\operatorname{Score}_{i, t}$ with a significance level of $5 \%$ for the sub-sample of low managerial ownership in column (4). These findings support our hypothesis $\mathrm{H} 2$ and suggest that the negative relationship is more pronounced for firms with lower managerial ownership. These findings are also consistent with Jia and Zhang (2013), who document a positive relationship between managerial ownership and CSR for Chinese firms.

\section{< Insert Table 8 about here>}

Third, we investigate the impact of internal control quality on the negative relationship. We expect that, as important internal governance mechanisms, strong internal controls would mitigate the impact of the decreased monitoring intensity of institutional investors on managers' CSR decisions. We measure firms' internal control quality with their DIB internal control index values obtained from the DIB internal 
control and risk management firms in China ${ }^{13}$. Constructed from five perspectives, namely, the internal environment, risk evaluation, control activities, information and communication, and internal monitoring, the DIB internal control index is widely used in studies related to the internal controls of Chinese listed firms ( $\mathrm{Lu}$ and Cao 2018; Wang et al. 2018). We classify a firm-year observation into the sub-sample of high internal control quality if its DIB internal control index value is above the sample median in a given year; otherwise, we classify it into the sub-sample of low internal control quality. Panel A of Table 9 reports the regression results of the model (3) with the two sub-samples. The coefficient of $\operatorname{InAtt}_{i, t}$ is positive and statistically insignificant for the sub-sample of high internal control quality and is significantly negative for the sub-sample of low internal control quality. Again, this finding is consistent with hypothesis $\mathrm{H} 2$, which states that the negative relationship between institutional investor inattention and CSR is more pronounced with lower internal control quality.

Finally, we investigate the impact of analyst coverage on the negative relationship. Analyst coverage serves as an external governance mechanism and therefore affects managers' CSR decisions (Adhikari 2016). Therefore, as stated in hypothesis H2, we expect the negative relationship to be more pronounced for firms with less analyst coverage. Again, we divided our sample into two sub-samples and studied the relationship between $\operatorname{InAtt}_{i, t}$ and Score $_{i, t}$. Firms are classified into the high analyst coverage sub-sample if their analyst coverage is above the sample median and otherwise are classified into the low analyst coverage sub-sample. In column (3) of

\footnotetext{
13 http://www.ic-erm.com/pro2.html
} 
Table 9, where the high analyst coverage sub-sample is studied, InAtti,t is only insignificantly related to $\operatorname{Score}_{i, t .}$ In contrast, InAtt $i, t$ is negatively related to $\operatorname{Score}_{i, t}$ with a significance level of $10 \%$ (t-statistics=-1.94) in column (4), where the sub-sample of low analyst coverage is studied. These findings again support our hypothesis H2.

To summarize, the sub-sample analysis in Table 8 and Table 9 suggests that, as expected by hypothesis $\mathrm{H} 2$, the significant negative relationship between institutional investor inattention and CSR is more pronounced for firms with higher expense ratios, less managerial ownership, weaker internal control, and less analyst coverage.

\section{< Insert Table 9 about here>}

\subsection{The impact of different groups of institutional investors}

\subsubsection{Institutional investors grouped by institution type}

To test $\mathrm{H} 3 \mathrm{a}$, we classify institutional investors into ten groups according to their institution types, namely, insurance companies, public mutual funds, the national social security fund, exchange-traded funds, overseas institutional investors ${ }^{14}$, corporate annuity plans, banks, trust companies, brokerage firms, and private investment funds. We calculate the yearly inattention of each institutional investor with the model (1) and aggregate them at institution group-firm level (denoted as $\left.\operatorname{InAttI}_{i, t}^{n}, \mathrm{n}=1,2, \ldots, 10\right)$. We then regress $\operatorname{Score}_{i, t}$ on $\operatorname{InAttI}_{i, t}^{n} \quad$ separately and report the regression results in columns (1) to (10) in Table 10. InAttI $_{i, t}^{n}$ is significantly and negatively related to Score $_{i, t}$ in columns (1), (2) and (3), where $\operatorname{InAttI}_{i, t}^{n}$ proxies for the inattention of insurance

\footnotetext{
${ }^{14}$ Overseas institutional investors in the Chinese A-share market include Qualified Foreign Institutional Investors (QFII), RMB Qualified Foreign Institutional Investors (RQFII) and other overseas institutional investors that are able to trade stocks of Chinese A-share listed firms with the Shanghai-Hong Kong Stock Connect program or the Shenzhen-Hong Kong Stock Connect program.
} 
companies, mutual funds, and the social security fund, respectively. In the remaining columns in Table 10, InAttI $I_{i, t}^{n}$ is insignificantly related to Score $_{i, t .}$

The institutional ownership of insurance companies, mutual funds, and the national social security fund rank in the top 3 among the ten types of institutional investors. They hold approximately $42 \%, 31 \%$ and $5 \%$ institutional ownership of Chinese A-share listed firms in our sample period, respectively ${ }^{15}$. The institutional ownership of other institutions is relatively minor. Meanwhile, insurance companies and the national social security fund have relatively long investment horizons. The national security fund is run by a committee directly supervised by the Ministry of Finance of China and is supposed to provide financial support for nationwide social security needs. Therefore, the results in Table 10 are consistent with hypothesis H3a, which states that the negative relationship between institutional investor inattention and CSR is more strongly attributable to institutions with influential ownership and/or long investment horizons. Our findings are also consistent with Sandberg (2013), who argues that long-term investors demand high CSR engagement to minimize the external costs caused by poor social or environmental performances.

\section{< Insert Table 10 about here>}

\subsubsection{Institutional investor groups classified by investment styles}

To test H3b, we follow Bushee (1998) and Bushee and Noe (2000) to classify institutional investors into dedicated institutional investors, transient institutional investors and quasi-indexers according to their portfolio concentration, portfolio

\footnotetext{
15 The national security fund is actually the largest single institutional investor in China. By the end of 2017, the market value of A-share stocks held by the national security fund was over 240 billion yuan (or 35 billion dollars). 
turnover, and trading strategies. To be more specific, following Bushee (1998), we use four variables for portfolio concentration, two variables for portfolio turnover, and three variables regarding sensitivity to current earnings to describe the past investment behaviors of institutional investors ${ }^{16}$. We perform principal factor analysis to combine the nine variables into three common factors and then perform k-means cluster analysis on the factor scores to obtain the final separation of institutional investors. According to Bushee (1998), we then define institutional investors with high portfolio concentration, low portfolio turnover and low trading sensitivity to earnings as dedicated institutional investors based on their corresponding factor scores. Similarly, we define transient institutional investors as those with the highest portfolio turnover and the highest use of momentum strategies and define quasi-indexers as those exhibiting buy-and-hold trading strategies.

We then measure the inattention of dedicated institutional investors, transient institutional investors, and quasi-indexers and denote them as $\operatorname{InAtt} D_{i, t}, \operatorname{InAtt} T_{i, t}$ and $\operatorname{InAtt} Q_{i, t}$, respectively. We regress Score $_{i, t}$ on $\operatorname{InAtt} D_{i, t}, \operatorname{InAtt} T_{i, t}$ and $\operatorname{InAtt} Q_{i, t}$ and report regression results in Table 11 . As shown in Table 11 , both $\operatorname{InAtt} D_{i, t}$ and $\operatorname{InAtt} Q_{i, t}$ are negatively related to $\operatorname{Score}_{i, t}$ with a significance level of $5 \%$, while $\operatorname{InAtt} T_{i, t}$ is insignificantly related to Score $_{i, t}$, suggesting that only the inattention of dedicated institutional investors and quasi-indexers shows a significant negative impact on CSR. These findings are consistent with hypothesis $\mathrm{H} 3 \mathrm{~b}$ and prior studies suggesting that dedicated institutional investors and quasi-indexers are active monitors in the stock

\footnotetext{
16 Please see Bushee (1998) for detailed descriptions of the nine variables.
} 
market, while transient institutional investors have relatively low incentives to monitor managers (Appel et al. 2016; Borochin and Yang 2017).

\section{< Insert Table 11 about here>}

\section{Conclusions}

We investigate the impact of institutional investors on CSR engagement of listed firms in China. To avoid endogeneity concerns on the two-way causality between institutional ownership and CSR engagement, we study how managers adjust their CSR decisions when their institutional investors are distracted by exogenous attentiongrabbing events and are thus inattentive. Using extreme industry returns as exogenous attention-grabbing events, we find a robust and negative relationship between institutional investor inattention and CSR. Further tests show that firms are less frequently visited by institutional investors when they are more inattentive to these firms. These findings suggest that the negative relationship is attributable to the principal conflict between managers and institutional investors. Managers are less motivated to engage in CSR when they are less monitored by institutional investors.

Consistent with this argument, we find that the negative relationship is more pronounced for firms with higher expense ratios, less managerial ownership, weaker internal controls, and less analyst coverage, i.e., firms with more serious principal-agent problems or weaker corporate governances. Additionally, the negative relationship is more attributable to the inattention of institutional investors with larger monitoring incentives, that is, institutional investors with influential firm share fractions and/or long investment horizons, dedicated institutional investors and quasi-indexers. 
The findings in our study suggest that institutional investors of Chinese listed firms demand CSR engagement, which in turn indicates that CSR is beneficial to shareholders for listed firms in China, the largest emerging market in the world. Therefore, we provide new empirical evidence on the debate on whether CSR is beneficial or harmful for shareholders and offer new insights into the relationship between institutional investors and CSR in emerging markets. We also extend the literature on limited attention in behavioral finance. Our study suggests that although institutional investors might be helpful in improving CSR performance for Chinese listed firms, their positive impact on CSR may be constrained by their limited attention. Managers are less motivated to create firm value through CSR when their institutional investors temporarily supply sub-optimal monitoring capacity as a result of limited attention.

Additionally, by studying the relationship between CSR engagement and institutional investors' attention variation caused by exogenous attention-grabbing events, our study is free from endogeneity concerns and thus provides meaningful insights for future studies regarding the impact of institutional investors on CSR actions. Although we use extreme industry returns as exogenous attention-grabbing events, events such as firm-specific news coverage and stock index re-constitutions may also be suitable to measure exogenous attention shocks. How these events induce institutional investors' attention variation and thus affect corporate actions, including CSR engagement, is also of interest for future studies.

Acknowledgments This study was supported by the China Postdoctoral Science Foundation (Grant No. 2018M643401), the Natural Science Foundation of Chongqing, 
China (cstc2019jcyj-bshX0087), the National Natural Science Foundation of China (Grant No. 71772019, 71973018) and the Fundamental Research Funds for the Central Universities (Grant No. 2019CDSKXYJG0037). 


\section{Appendix}

Variable definitions

\begin{tabular}{|c|c|c|}
\hline Variables & Definitions & Data sources \\
\hline Score $_{i, t}$ & The total RKS CSR score of firm $i$ in year $t$. & RKS \\
\hline$M_{i, t}$ & The RKS macrocosm score of firm $i$ in year $t$. & RKS \\
\hline$C_{i, t}$ & The RKS content score of firm $i$ in year $t$. & RKS \\
\hline$T_{i, t}$ & The RKS technique score of firm $i$ in year $t$. & RKS \\
\hline$I_{i, t}$ & The RKS industry score of firm $i$ in year $t$. & RKS \\
\hline$D D i s_{i, t}$ & Dummy that equals 1 if firm $i$ volunteers to disclose its CSR report in year $t$. & RKS \\
\hline HXScore $_{i, t}$ & The total CSR score of firm $i$ in year $t$ assigned by hexun.com. & hexun.com. \\
\hline SHolder $_{i, t}$ & The shareholder responsibility score of firm $i$ in year $t$ assigned by hexun.com. & hexun.com. \\
\hline Employee $_{i, t}$ & The employee responsibility score of firm $i$ in year $t$ assigned by hexun.com. & hexun.com. \\
\hline Customer $_{i, t}$ & The customer responsibility score of firm $i$ in year $t$ assigned by hexun.com. & hexun.com. \\
\hline Envir $_{i, t}$ & $\begin{array}{l}\text { The environmental responsibility score of firm } i \text { in year } t \text { assigned by } \\
\text { hexun.com. }\end{array}$ & hexun.com. \\
\hline Social $_{, t}$ & The social responsibility score of firm $i$ in year $t$ assigned by hexun.com. & hexun.com. \\
\hline DVisit ${ }_{i, t}$ & $\begin{array}{l}\text { Dummy that equals } 1 \text { if firm } i \text { is visited by institutional investors at least once } \\
\text { in year } t \text { and } 0 \text { otherwise. }\end{array}$ & $\begin{array}{l}\text { Firm annual } \\
\text { reports }\end{array}$ \\
\hline NVisit $t_{, t}$ & $\begin{array}{l}\text { The } \log \text { of } 1 \text { plus the number of times firm } i \text { is visited by institutional investors } \\
\text { in year } t \text {. }\end{array}$ & $\begin{array}{l}\text { Firm annual } \\
\text { reports }\end{array}$ \\
\hline$D_{M a n u}, t$ & Dummy that equals 1 if firm $i$ is in the manufacturing industry and 0 otherwise. & CSMAR \\
\hline DRate $_{i, t}$ & $\begin{array}{l}\text { Dummy that equals } 1 \text { if the information disclosure quality of firm } i \text { is relatively } \\
\text { poor and hence is rated as C or D by the Shenzhen Stock Exchange (SZSE) and } \\
0 \text { otherwise. }\end{array}$ & CSMAR \\
\hline $\operatorname{Ret}_{i, t}$ & The market-adjusted stock return of firm $i$ in year $t$ & CSMAR \\
\hline$A g e_{i, t}$ & The log of years for which firm $i$ has been listing in SZSE. & CSMAR \\
\hline MShare $_{i, t}$ & The market share of firm $i$ in year $t$. & CSMAR \\
\hline NFirms $_{i, t}$ & $\begin{array}{l}\text { The log of the total number of listed firms in the city where firm } i \text { is } \\
\text { headquartered. }\end{array}$ & CSMAR \\
\hline \multirow[t]{2}{*}{ GDPGrowth $_{i, t}$} & The GDP growth of the city where firm $i$ is headquartered. & CSMAR \\
\hline & & CSMAR \\
\hline InAtti, & $\begin{array}{l}\text { The firm-level measure of institutional investor inattention following (Kempf et } \\
\text { al. 2017). }\end{array}$ & Wind \\
\hline $\operatorname{InAttI} I_{i, t}^{n}$ & $\begin{array}{l}\text { The firm-level inattention of the } \mathrm{n}^{\text {th }} \text { institution type of institutional investors, } \\
\mathrm{n}=1,2, \ldots, 10 \text {. Types } 1 \text { to } 10 \text { refers to insurance companies, public mutual funds, } \\
\text { the national social security fund, exchange-traded funds, overseas institutional } \\
\text { investors, corporate annuity plans, banks, trust companies, brokerage firms, and } \\
\text { private investment funds, respectively. }\end{array}$ & Wind \\
\hline $\operatorname{InAtt} D_{i, t}$ & The firm-level inattention of dedicated institutional investors. & Wind \\
\hline $\operatorname{InAtt} T_{i, t}$ & The firm-level inattention of transient institutional investors. & Wind \\
\hline $\operatorname{InAtt} Q_{i, t}$ & The firm-level inattention of quasi-indexers. & Wind \\
\hline$B M_{i, t}$ & Book value of assets over the market value of assets. & CSMAR \\
\hline Size $_{i, t}$ & The log of total year-end assets (in billion yuan). & CSMAR \\
\hline$R O A_{i, t}$ & The return on assets in the year of $t$. & CSMAR \\
\hline$L e v_{i, t}$ & Total debt divided by total assets. & CSMAR \\
\hline$S O E_{i, t}$ & Dummy that equals 1 for state-owned enterprises and equals 0 otherwise. & CSMAR \\
\hline Capex $_{i, t}$ & Capital expenditure scaled by total assets. & CSMAR \\
\hline$A C_{i, t}$ & The log of the number of analysts following in year $t$ & CSMAR \\
\hline$I O_{i, t}$ & The total share percentage of institutional investors by the end of year $t$. & CSMAR \\
\hline BInep $_{i, t}$ & The percentage of independent board directors. & CSMAR \\
\hline$B$ Size $e_{i, t}$ & The log of the number of board directors. & CSMAR \\
\hline Duality $_{i, t}$ & Dummy that equals 1 if the CEO also chairs the board. & CSMAR \\
\hline$M O_{i, t}$ & The share percentage of the top management team by the end of year $t$. & CSMAR \\
\hline TOP $1_{i, t}$ & The share percentage of the largest shareholder by the end of year $t$. & CSMAR \\
\hline$H H I 5_{i, t}$ & The Herfindahl-Hirschmann Index of share percentage of the top 5 shareholders. & CSMAR \\
\hline
\end{tabular}




\section{References}

Adhikari BK (2016) Causal effect of analyst following on corporate social responsibility. Journal of Corporate Finance 41:201-216

Allen F, Qian J, Qian MJ (2005) Law, finance, and economic growth in China. Journal of Financial Economics, 77(1):57-116

Aggarwal R, Erel I, Ferreira M, Matos P (2011) Does governance travel around the world? Evidence from institutional investors. Journal of Financial Economics 100(1):154-181

Ang JS, Cole RA, Lin JW (2000) Agency costs and ownership structure. Journal Of Finance 55(1):81106

Appel IR, Gormley TA, Keim DB (2016) Passive investors, not passive owners. Journal of Financial Economics 121(1):111-141

Baker M, Wurgler J (2013) Behavioral corporate finance: An updated survey, Handbook of the Economics of Finance 2:357-424

Barber BM, Odean T (2008) All that glitters: The effect of attention and news on the buying behavior of individual and institutional investors. Review of Financial Studies 21(2):785-818

Barnea A, Rubin A (2010) Corporate social responsibility as a conflict between shareholders. Journal of Business Ethics 97(1):71-86

Ben-Rephael A, Da Z, Israelsen RD (2017) It depends on where you search: Institutional investor attention and underreaction to news. Review of Financial Studies 30(9):3009-3047

Benabou R, Tirole J (2010) Individual and corporate social responsibility. Economica 77(305):1-19

Bird A, Karolyi SA (2016) Do institutional investors demand public disclosure? Review of Financial Studies 29(12):3245-3277

Boone AL, White JT (2015) The effect of institutional ownership on firm transparency and information production. Journal of Financial Economics 117(3):508-533

Borochin P, Yang J (2017) The effects of institutional investor objectives on firm valuation and governance. Journal of Financial Economics 126(1):171-199

Bushee BJ (1998) The influence of institutional investors on myopic R\&D investment behavior. Accounting Review 73(3):305-333

Bushee BJ, Noe CF (2000) Corporate disclosure practices, institutional investors, and stock return volatility. Journal of Accounting Research 38:171-202

Cheng H, Hong H, Shue K (2016). Do managers do good with other people's money. Unpublished working paper. Darthmouth College, Princeton University, and University of Chicago.

Cheng Q, Du F, Wang YT, Wang X (2019) Do corporate site visits impact stock prices? Contemporary Accounting Research 36(1):359-388 
Cheng, Q, Du F, Wang X, Wang Y T (2016b) Seeing is believing: analysts' corporate site visits. Review of Accounting Studies 21(4):1245-1286

Choi BB, Lee D, Park Y (2013) Corporate social responsibility, corporate governance and earnings quality: Evidence from Korea. Corporate Governance-an International Review 21(5):447-467

Cox P, Brammer S, Millington A (2004) An empirical examination of institutional investor preferences for corporate social performance. Journal of Business Ethics 52(1):27-43

Cui J, Jo H, Na H (2018) Does corporate social responsibility affect information asymmetry? Journal of Business Ethics 148(3):549-572

Da Z, Engelberg J, Gao PJ (2011) In search of attention. Journal of Finance 66(5):1461-1499

Da Z, Gurun UG, Warachka M (2014) Frog in the pan: Continuous information and momentum. Review of Financial Studies 27(7):2171-2218

Dyck A, Lins KV, Roth L, Wagner HE (2019) Do institutional investors drive corporate social responsibility? International evidence. Journal of Financial Economics 131(3):693-714

Elfenbein DW, Fisman R, Mcmanus B (2012) Charity as a substitute for reputation: Evidence from an online marketplace. Review of Economic Studies 79(4):1441-1468

Faller CM, Knyphausen-Aufsess DZ (2018) Does equity ownership matter for corporate social responsibility? A literature review of theories and recent empirical findings. Journal of Business Ethics 150(1):15-40

Fauver L, Fuerst ME (2006) Does good corporate governance include employee representation? Evidence from German corporate boards. Journal of Financial Economics 82(3):673-710

Fernandez-Gago R, Cabeza-Garcia L, Nieto M (2016) Corporate social responsibility, board of directors, and firm performance: an analysis of their relationships. Review of Managerial Science, 10(1): $85-104$

Ferrell A, Liang H, Renneboog L (2016) Socially responsible firms. Journal of Financial Economics 122(3):585-606

Goh BW, Li D (2011) Internal controls and conditional conservatism. Accounting Review 86(3):9751005

Gong GM, Xu S, Gong X (2018) On the value of corporate social responsibility disclosure: An empirical investigation of corporate bond issues in China. Journal of Business Ethics 150(1):227-258

Han B, Kong DM, Liu SS (2018) Do analysts gain an informational advantage by visiting listed companies? Contemporary Accounting Research 35(4):1843-1867

Harjoto MA, Jo H (2011) Corporate governance and CSR nexus. Journal of Business Ethics 100(1):4567

He W, Luo JH (2018) Agency problems in firms with an even number of directors: Evidence from China. 
Journal Of Banking \& Finance, 93, 139-150

Jia M, Zhang Z (2013) Managerial ownership and corporate social performance: Evidence from privately owned Chinese firms' response to the Sichuan earthquake. Corporate Social Responsibility And Environmental Management 20(5):257-274

Jiang GH, Lee CMC, \& Yue H (2010) Tunneling through intercorporate loans: The China experience. Journal of Financial Economics, 98(1):1-20.

Jiang GH, Rao PG, Yue H (2015) Tunneling through non-operational fund occupancy: An investigation based on officially identified activities. Journal of Corporate Finance 32:295-311

Kacperczyk M, Van Nieuwerburgh S, Veldkamp L (2016) A rational theory of mutual funds' attention allocation. Econometrica 84(2):571-626

Kahneman, D (1973). Attention and effort. Prentice-Hall, NJ, Englewood Cliffs.

Kempf E, Manconi A, Spalt O (2017) Distracted shareholders and corporate actions. Review of Financial Studies 30(5):1660-1695

Lau CM, Lu Y, Liang Q (2016) Corporate social responsibility in China: A corporate governance approach. Journal of Business Ethics 136(1):73-87

Liao L, Lin T, Zhang YY (2018) Corporate board and corporate social responsibility assurance: Evidence from China. Journal of Business Ethics 150(1):211-225

Lins KV, Servaes H, Tamayo A (2017) Social capital, trust, and firm performance: The value of corporate social responsibility during the financial crisis. Journal of Finance 72(4):1785-1823

Lockett A, Moon J, Visser W (2006) Corporate social responsibility in management research: Focus, nature, salience and sources of influence. Journal Of Management Studies 43(1):115-136

Lu Y, Cao Y (2018) The individual characteristics of board members and internal control weakness: Evidence from China. Pacific-Basin Finance Journal 51:75-94

Lu Y, Ray S, Teo M (2016) Limited attention, marital events and hedge funds. Journal of Financial Economics 122(3):607-624

Marquis C, Qian CL (2014) Corporate social responsibility reporting in China: Symbol or substance? Organization Science 25(1):127-148

Martinez-Ferrero J, Garcia-Sanchez, IM (2015) Is corporate social responsibility an entrenchment strategy? Evidence in stakeholder protection environments. Review of Managerial Science, 9(1): 89-114

Martinez-Ferrero J, Rodriguez-Ariza L, Garcia-Sanchez IM \& Cuadrado-Ballesteros B (2018) Corporate social responsibility disclosure and information asymmetry: the role of family ownership. Review of Managerial Science, 12(4):885-916

Masulis RW, Reza SW (2015) Agency problems of corporate philanthropy. Review of Financial Studies 
28(2):592-636

Petersen HL, Vredenburg H (2009) Morals or economics? Institutional investor preferences for corporate social responsibility. Journal of Business Ethics 90(1):1-14

Reverte C (2016) Corporate social responsibility disclosure and market valuation: evidence from Spanish listed firms. Review of Managerial Science, 10(2):411-435

Sandberg J (2013) (Re-)Interpreting fiduciary duty to justify socially responsible investment for pension funds? Corporate Governance-an International Review 21(5):436-446

Servaes H, Tamayo A (2013) The impact of corporate social responsibility on firm value: The role of customer awareness. Management Science 59(5):1045-1061

Schmidt, D (2019) Distracted Institutional Investors. Journal Of Financial And Quantitative Analysis, 54(6): 2453-2491

Shafer WE, Fukukawa K, Lee GM (2007) Values and the perceived importance of ethics and social responsibility: The US versus China. Journal of Business Ethics, 70(3):265-284

Tian ZL, Wang R, Yang W (2011) Consumer responses to corporate social responsibility (CSR) in China. Journal Of Business Ethics 101(2):197-212

Tirole J (2001) Corporate governance. Econometrica 69(1):1-35

Wang KT, Li DJ (2016) Market reactions to the first-time disclosure of corporate social responsibility reports: Evidence from China. Journal of Business Ethics 138(4):661-682

Wang MB, Qiu C, Kong DM (2011) Corporate social responsibility, investor behaviors, and stock market returns: Evidence from a natural experiment in China. Journal of Business Ethics 101(1):127141

Wang X, Cao F, Ye KT (2018) Mandatory corporate social responsibility (CSR) reporting and financial reporting quality: Evidence from a quasi-natural experiment. Journal of Business Ethics 152(1):253-274

Ye KT, Zhang R (2011) Do Lenders value corporate social responsibility? Evidence from China. Journal of Business Ethics 104(2):197-206

Yin JL, Zhang YL (2012) Institutional dynamics and corporate social responsibility (CSR) in an emerging country context: Evidence from China. Journal of Business Ethics 111(2):301-316

Zhang J, Kong DM, Wu J (2018) Doing good business by hiring directors with foreign experience. Journal of Business Ethics 153(3):859-876 
Table 1 Summary statistics

This table reports summary statistics for the main variables in this study. InAtt $t_{i, t}$ is a firm-level measure of institutional investor inattention following Kempf et al. (2017). Score $e_{i, t}, M_{i, t}, C_{i, t}, T_{i, t}$, and $I_{i, t}$ are the total and sub-categories of RKS CSR scores, respectively. $B M_{i, t}$ is the book value of assets over the market value of assets. Size $e_{i, t}$ is the log of total year-end assets (in billion yuan). $R O A_{i, t}$ is the return on assets in year $t . \operatorname{Lev}_{i, t}$ is the total debt divided by total assets. $S O E_{i, t}$ is a dummy that equals 1 for stateowned enterprises and 0 otherwise. Capex $x_{i, t}$ is capital expenditures scaled by total assets. $A C_{i, t}$ is the log of the number of following analysts in year $t . I O_{i, t}$ is the total share percentage of institutional investors by the end of year $t$. BInep $i, t$ is the percentage of independent board directors. BSize $i, t$ is the log of the number of board directors. Duality $y_{i, t}$ is a dummy that equals 1 if the CEO also chairs the board. $M O_{i, t}$ is the share percentage of the top management team by the end of year $t . T O P 1_{i, t}$ is the share percentage of the largest shareholder by the end of year $t . H H I 5_{i, t}$ is the Herfindahl-Hirschmann Index of the share percentage of the top 5 shareholders.

\begin{tabular}{lcccccc}
\hline Variables & \# of obs & Mean & SD & P25 & Median & P75 \\
\hline InAtt $_{i, t}($ RAW & 12,556 & 0.0574 & 0.0900 & 0.0038 & 0.0202 & 0.0699 \\
Score $_{i, t}$ & 12,556 & 21.9686 & 21.5829 & 0 & 25.8832 & 37.6586 \\
$M_{i, t}$ & 10,242 & 7.2992 & 7.4441 & 0 & 7.266 & 13.1300 \\
$C_{i, t}$ & 10,242 & 9.5719 & 9.7249 & 0 & 10.5469 & 16.9400 \\
$T_{i, t}$ & 10,242 & 3.8109 & 3.7532 & 0 & 4.9632 & 6.6176 \\
$I_{i, t}$ & 8,243 & 1.0937 & 1.6662 & 0 & 0 & 1.6667 \\
BM $_{i, t}$ & 12,556 & 0.9247 & 0.9849 & 0.3561 & 0.6099 & 1.0971 \\
Size $_{i, t}$ & 12,556 & 0.5629 & 1.4517 & -0.4460 & 0.5465 & 1.5550 \\
ROA $_{i, t}$ & 12,556 & 0.0445 & 0.0629 & 0.0249 & 0.0465 & 0.0728 \\
Lev $_{i, t}$ & 12,556 & 0.4629 & 0.2305 & 0.2933 & 0.4528 & 0.6133 \\
SOE $_{i, t}$ & 12,556 & 0.4723 & 0.4992 & 0 & 0 & 1 \\
Capex $_{i, t}$ & 12,556 & 0.0504 & 0.0497 & 0.0137 & 0.0354 & 0.0710 \\
AC $_{i, t}$ & 12,556 & 1.1900 & 1.1574 & 0 & 1.0986 & 2.1972 \\
IO $_{i, t}$ & 12,556 & 0.1805 & 0.1901 & 0.0323 & 0.1093 & 0.2716 \\
BInep $_{i, t}$ & 12,556 & 0.3513 & 0.0822 & 0.3333 & 0.3333 & 0.7846 \\
BSize $_{i, t}$ & 12,556 & 2.2851 & 0.1914 & 2.1972 & 2.3026 & 2.3026 \\
Duality $_{i, t}$ & 12,556 & 0.2325 & 0.4224 & 0 & 0 & 0 \\
MO $_{i, t}$ & 12,556 & 0.0537 & 0.1261 & 0 & 0.0001 & 0.0165 \\
TOP $_{i, t}$ & 12,556 & 0.3526 & 0.1518 & 0.2325 & 0.3324 & 0.4570 \\
HHI5 $_{i, t}$ & 12,556 & 0.1673 & 0.1189 & 0.0755 & 0.1385 & 0.2318 \\
\hline
\end{tabular}


Table 2 Pearson correlation matrix and variance inflation factors

This table reports the correlation matrix and variance inflation factors of the main variables in this study. All variables are defined in the appendix.

\begin{tabular}{|c|c|c|c|c|c|c|c|c|c|c|c|c|c|c|c|}
\hline \multicolumn{16}{|c|}{ Panel A Pearson correlation matrix } \\
\hline & Score & InAtt & Size & $B M$ & $R O A$ & Lev & Capex & $A C$ & SOE & TOP1 & $I O$ & $M O$ & HH5 & Duality & BSize \\
\hline Score & 1 & & & & & & & & & & & & & & \\
\hline InAtt & -0.409 & 1 & & & & & & & & & & & & & \\
\hline Size & 0.466 & -0.131 & 1 & & & & & & & & & & & & \\
\hline$B M$ & 0.278 & -0.108 & 0.081 & 1 & & & & & & & & & & & \\
\hline$R O A$ & -0.049 & 0.175 & 0.160 & -0.164 & 1 & & & & & & & & & & \\
\hline Lev & 0.167 & -0.069 & 0.046 & 0.473 & -0.338 & 1 & & & & & & & & & \\
\hline Capex & 0.055 & -0.028 & 0.216 & 0.044 & 0.049 & -0.018 & 1 & & & & & & & & \\
\hline$A C$ & 0.223 & 0.261 & 0.552 & 0.00700 & 0.339 & -0.151 & 0.242 & 1 & & & & & & & \\
\hline$S O E$ & 0.110 & 0.026 & 0.054 & 0.258 & -0.085 & 0.222 & -0.115 & -0.102 & 1 & & & & & & \\
\hline TOP1 & 0.027 & 0.009 & 0.045 & 0.111 & 0.108 & 0.020 & 0.041 & 0.116 & 0.207 & 1 & & & & & \\
\hline$I O$ & 0.181 & 0.038 & 0.387 & 0.051 & 0.081 & 0.020 & 0.117 & 0.256 & 0.016 & 0.073 & 1 & & & & \\
\hline$M O$ & 0.088 & 0.008 & -0.099 & -0.214 & 0.134 & -0.294 & 0.125 & 0.184 & -0.380 & -0.030 & -0.091 & 1 & & & \\
\hline HH5 & -0.041 & 0.132 & -0.077 & -0.089 & 0.133 & -0.121 & -0.015 & 0.206 & -0.072 & 0.050 & -0.053 & 0.124 & 1 & & \\
\hline Duality & 0.067 & -0.010 & 0.058 & 0.124 & 0.120 & 0.009 & 0.049 & 0.140 & 0.179 & 0.960 & 0.085 & -0.015 & 0.049 & 1 & \\
\hline BSize & -0.051 & -0.024 & -0.071 & -0.145 & 0.041 & -0.146 & 0.108 & 0.047 & -0.278 & -0.049 & -0.020 & 0.465 & 0.068 & -0.047 & 1 \\
\hline BIndep & 0.176 & -0.0160 & 0.072 & 0.229 & 0.020 & 0.136 & -0.310 & 0.074 & 0.271 & 0.015 & 0.012 & -0.174 & 0.024 & 0.036 & -0.182 \\
\hline \multicolumn{16}{|c|}{ Panel B Variance inflation factor } \\
\hline \multirow{2}{*}{\multicolumn{2}{|c|}{ VIF }} & $\operatorname{InAtt}$ & Size & $B M$ & $R O A$ & Lev & Capex & $A C$ & $S O E$ & TOP1 & $I O$ & $M O$ & HH5 & Duality & BSize \\
\hline & & 1.21 & 1.57 & 1.35 & 1.37 & 1.85 & 1.21 & 1.67 & 1.26 & 4.53 & 1.05 & 1.29 & 1.12 & 4.57 & 1.19 \\
\hline
\end{tabular}


Table 3 Baseline regression results

This table reports the OLS regression results of the model (3) with a sample of Chinese listed firms from 2009-2017. All variables are defined in the appendix. For the convenience of interpretation, InAtti, is standardized to have zero mean and unit variance in all regressions. Year and industry fixed effects are included in all regressions. The t-statistics in parentheses are based on robust standard errors. *,**, and *** denote significance levels of $10 \%, 5 \%$, and $1 \%$, respectively.

\begin{tabular}{|c|c|c|c|c|c|}
\hline & (1) & (2) & (3) & (4) & (5) \\
\hline & Score $_{i, t}$ & $M_{i, t}$ & $C_{i, t}$ & $T_{i, t}$ & $I_{i, t}$ \\
\hline$I_{n A t t}$ & $\begin{array}{c}-0.554 * * \\
(-1.99)\end{array}$ & $\begin{array}{c}-0.306 * * * \\
(-3.27)\end{array}$ & $\begin{array}{c}-0.142 * * \\
(-2.01)\end{array}$ & $\begin{array}{l}-0.049 \\
(-0.93)\end{array}$ & $\begin{array}{c}-0.086 * * * \\
(-4.39)\end{array}$ \\
\hline$S i z e_{i, t}$ & $\begin{array}{c}8.462 * * * \\
(26.15)\end{array}$ & $\begin{array}{c}2.936 * * * \\
(26.44)\end{array}$ & $\begin{array}{c}3.713 * * * \\
(24.86)\end{array}$ & $\begin{array}{c}1.407 * * * \\
(25.13)\end{array}$ & $\begin{array}{c}0.600 * * * \\
(22.49)\end{array}$ \\
\hline$B M_{i, t}$ & $\begin{array}{c}3.817 * * * \\
(14.40)\end{array}$ & $\begin{array}{c}1.282 * * * \\
(14.39)\end{array}$ & $\begin{array}{c}1.682 * * * \\
(13.73)\end{array}$ & $\begin{array}{c}0.677 * * * \\
(14.59)\end{array}$ & $\begin{array}{c}0.354 * * * \\
(14.06)\end{array}$ \\
\hline$R O A_{i, t}$ & $\begin{array}{c}-19.500 * * * \\
(-3.09)\end{array}$ & $\begin{array}{c}-7.604 * * * \\
(-3.55)\end{array}$ & $\begin{array}{c}-8.799 * * * \\
(-3.05)\end{array}$ & $\begin{array}{c}-2.748 * * \\
(-2.51)\end{array}$ & $\begin{array}{c}-1.495 * * * \\
(-3.64)\end{array}$ \\
\hline $\operatorname{Lev}_{i, t}$ & $\begin{array}{c}-7.234 * * * \\
(-4.68)\end{array}$ & $\begin{array}{c}-2.780 * * * \\
(-5.26)\end{array}$ & $\begin{array}{c}-3.158 * * * \\
(-4.43)\end{array}$ & $\begin{array}{c}-1.338 * * * \\
(-4.91)\end{array}$ & $\begin{array}{c}-0.642 * * * \\
(-5.87)\end{array}$ \\
\hline Capex $_{i, t}$ & $\begin{array}{c}10.072 * \\
(1.92)\end{array}$ & $\begin{array}{c}3.521^{*} \\
(1.95)\end{array}$ & $\begin{array}{c}5.094^{* *} \\
(2.05)\end{array}$ & $\begin{array}{c}1.959^{* *} \\
(2.09)\end{array}$ & $\begin{array}{l}0.449 \\
(1.06)\end{array}$ \\
\hline$A C_{i, t}$ & $\begin{array}{c}1.533 * * * \\
(5.15)\end{array}$ & $\begin{array}{c}0.300 * * * \\
(2.92)\end{array}$ & $\begin{array}{c}0.757 * * * \\
(5.54)\end{array}$ & $\begin{array}{c}0.233 * * * \\
(4.51)\end{array}$ & $\begin{array}{c}0.073 * * * \\
(3.48)\end{array}$ \\
\hline$S O E_{i, t}$ & $\begin{array}{c}4.546^{* * * *} \\
(7.93)\end{array}$ & $\begin{array}{c}1.354 * * * \\
(6.97)\end{array}$ & $\begin{array}{c}2.025 * * * \\
(7.66)\end{array}$ & $\begin{array}{c}0.747 * * * \\
(7.37)\end{array}$ & $\begin{array}{c}0.276^{* * *} \\
(6.40)\end{array}$ \\
\hline$T O P 1_{i, t}$ & $\begin{array}{c}-0.381 * * * \\
(-6.41)\end{array}$ & $\begin{array}{c}-0.121 * * * \\
(-5.91)\end{array}$ & $\begin{array}{c}-0.162 * * * \\
(-5.85)\end{array}$ & $\begin{array}{c}-0.060 * * * \\
(-5.69)\end{array}$ & $\begin{array}{c}-0.048 * * * \\
(-10.04)\end{array}$ \\
\hline$I O_{i, t}$ & $\begin{array}{c}5.142 * * * \\
(3.62)\end{array}$ & $\begin{array}{c}2.285^{* * *} * \\
(4.68)\end{array}$ & $\begin{array}{c}1.630 * * \\
(2.50)\end{array}$ & $\begin{array}{c}0.823 * * * \\
(3.39)\end{array}$ & $\begin{array}{c}0.508 * * * \\
(4.41)\end{array}$ \\
\hline$M O_{i, t}$ & $\begin{array}{c}6.148 * * \\
(2.07)\end{array}$ & $\begin{array}{l}1.113 \\
(1.05)\end{array}$ & $\begin{array}{c}3.227 * * \\
(2.51)\end{array}$ & $\begin{array}{c}1.086^{* *} \\
(2.03)\end{array}$ & $\begin{array}{l}0.291 \\
(1.57)\end{array}$ \\
\hline$H H 5_{i, t}$ & $\begin{array}{l}-1.516 \\
(-0.28)\end{array}$ & $\begin{array}{l}-1.818 \\
(-1.02)\end{array}$ & $\begin{array}{l}-0.574 \\
(-0.23)\end{array}$ & $\begin{array}{l}-0.630 \\
(-0.66)\end{array}$ & $\begin{array}{l}0.489 \\
(1.20)\end{array}$ \\
\hline Duality $_{i, t}$ & $\begin{array}{c}22.588 * * * \\
(7.07)\end{array}$ & $\begin{array}{c}6.773 * * * \\
(6.57)\end{array}$ & $\begin{array}{c}4.933 * * * \\
(6.58)\end{array}$ & $\begin{array}{c}3.091 * * * \\
(6.23)\end{array}$ & $\begin{array}{c}3.250 * * * \\
(10.39)\end{array}$ \\
\hline$B S i z e_{i, t}$ & $\begin{array}{c}0.790 \\
(1.07)\end{array}$ & $\begin{array}{l}0.260 \\
(1.02)\end{array}$ & $\begin{array}{l}0.331 \\
(0.97)\end{array}$ & $\begin{array}{c}0.113 \\
(0.87)\end{array}$ & $\begin{array}{l}0.008 \\
(0.16)\end{array}$ \\
\hline BIndep $_{i, t}$ & $\begin{array}{c}6.417 * * * \\
(3.96)\end{array}$ & $\begin{array}{c}1.892 * * * \\
(3.43)\end{array}$ & $\begin{array}{c}3.066^{* * * *} \\
(4.10)\end{array}$ & $\begin{array}{c}0.918^{* * * *} \\
(3.21)\end{array}$ & $\begin{array}{c}0.553 * * * \\
(4.06)\end{array}$ \\
\hline Constant & $\begin{array}{c}-20.399 * * * \\
(-4.15)\end{array}$ & $\begin{array}{c}-6.133 * * * \\
(-3.64) \\
\end{array}$ & $\begin{array}{c}-9.904 * * * \\
(-4.32) \\
\end{array}$ & $\begin{array}{c}-3.014 * * * \\
(-3.49) \\
\end{array}$ & $\begin{array}{c}-1.588 * * * \\
(-3.91) \\
\end{array}$ \\
\hline Year FE & Yes & Yes & Yes & Yes & Yes \\
\hline Industry $F E$ & Yes & Yes & Yes & Yes & Yes \\
\hline \# of obs & 12,556 & 10,242 & 10,242 & 10,242 & 8,243 \\
\hline $\operatorname{Adj}-R^{2}$ & 0.347 & 0.342 & 0.333 & 0.326 & 0.377 \\
\hline$F$-statistics & 214.815 & 206.632 & 200.717 & 192.335 & 103.663 \\
\hline
\end{tabular}


Table 4 Robust test: alternative proxies for CSR engagement

In this table, we check the robustness of the negative relationship between institutional investor inattention and CSR engagement with alternative CSR proxies. In column (1), we measure firms' CSR engagement with the dummy $D D i s_{i, t}$, which equals 1 if firm $i$ volunteers to disclose its CSR report in year $t$ and equals 0 otherwise. Firms that are mandated to disclose CSR reports according to the requirements of the China Security Regulation Committee (CSRC) are excluded in column (1). In columns (2) to (7), firms' CSR engagement is measured by their CSR scores assigned by hexun.com (HX), a leading financial media company in China. Since HX began rating CSR scores in 2010, the sample period in columns (2) to (7) is 2010-2017. HXScore indicates firms' total CSR scores, while SHolder, Employee, Customer, Envir, and Social indicate scores for shareholder responsibility, employee responsibility, customer responsibility, environmental responsibility, and social responsibility, respectively. For the convenience of interpretation, InAtt ${ }_{i, t}$ is standardized to have a zero mean and unit variance in all regressions. Year and industry fixed effects are included in all regressions. The z-statistics in parentheses of columns (1) and t-statistics in parentheses of columns (2) to (7) are based on robust standard errors. $* * *$, and $* * *$ denote significance levels of $10 \%, 5 \%$, and $1 \%$, respectively.

\begin{tabular}{|c|c|c|c|c|c|c|c|}
\hline & $\begin{array}{c}(1) \\
D D i s_{i, t}\end{array}$ & $\begin{array}{c}(2) \\
\text { HXScore }_{i, t}\end{array}$ & $\begin{array}{c}(3) \\
\text { SHolder }_{i, t}\end{array}$ & $\begin{array}{c}(4) \\
\text { Employee }_{i, t}\end{array}$ & $\begin{array}{c}(5 \\
\text { Customer }_{i, t}\end{array}$ & $\begin{array}{c}(6) \\
\text { Envir }{ }_{i, t}\end{array}$ & $\begin{array}{c}(7) \\
\text { Social }_{i, t}\end{array}$ \\
\hline InAtt $_{i, t}$ & $\begin{array}{c}-0.014 * * \\
(-2.33)\end{array}$ & $\begin{array}{c}-0.592^{*} \\
(-1.85)\end{array}$ & $\begin{array}{l}-0.004 \\
(-0.07)\end{array}$ & $\begin{array}{c}-0.292 * * * \\
(-4.36)\end{array}$ & $\begin{array}{c}-0.245^{* *} \\
(-2.35)\end{array}$ & $\begin{array}{c}-0.214^{*} \\
(-1.88)\end{array}$ & $\begin{array}{l}-0.025 \\
(-0.29)\end{array}$ \\
\hline Size $_{i, t}$ & $\begin{array}{c}0.814 * * * \\
(18.35)\end{array}$ & $\begin{array}{c}3.922 * * * \\
(11.37)\end{array}$ & $\begin{array}{c}0.410 * * * \\
(5.70)\end{array}$ & $\begin{array}{c}0.926 * * * \\
(12.54)\end{array}$ & $\begin{array}{c}1.127 * * * \\
(9.64)\end{array}$ & $\begin{array}{c}1.206 * * * \\
(9.80)\end{array}$ & $\begin{array}{c}0.274 * * * \\
(2.97)\end{array}$ \\
\hline$B M_{i, t}$ & $\begin{array}{c}0.396 * * * \\
(9.64)\end{array}$ & $\begin{array}{c}2.403 * * * \\
(8.23)\end{array}$ & $\begin{array}{c}0.573 * * * \\
(7.63)\end{array}$ & $\begin{array}{c}0.394 * * * \\
(6.05)\end{array}$ & $\begin{array}{c}0.256^{* * * *} \\
(2.73)\end{array}$ & $\begin{array}{c}0.378 * * * \\
(3.54)\end{array}$ & $\begin{array}{c}0.736 * * * \\
(7.65)\end{array}$ \\
\hline$R O A_{i, t}$ & $\begin{array}{c}-1.590 * \\
(-1.81)\end{array}$ & $\begin{array}{c}103.899 * * * \\
(15.86)\end{array}$ & $\begin{array}{c}84.029 * * * \\
(39.18)\end{array}$ & $\begin{array}{l}-0.414 \\
(-0.30)\end{array}$ & $\begin{array}{l}-0.942 \\
(-0.48)\end{array}$ & $\begin{array}{l}-1.173 \\
(-0.55)\end{array}$ & $\begin{array}{c}20.729 * * * \\
(12.65)\end{array}$ \\
\hline$L e v_{i, t}$ & $\begin{array}{c}-0.675^{* * *} \\
(-3.13)\end{array}$ & $\begin{array}{c}-4.709 * * * \\
(-2.82)\end{array}$ & $\begin{array}{c}-3.037 * * * \\
(-7.46)\end{array}$ & $\begin{array}{l}-0.592 \\
(-1.59)\end{array}$ & $\begin{array}{c}-1.737 * * * \\
(-3.09)\end{array}$ & $\begin{array}{c}-1.735^{* * *} * \\
(-3.06)\end{array}$ & $\begin{array}{c}2.310 * * * \\
(4.84)\end{array}$ \\
\hline Capex $_{i, t}$ & $\begin{array}{l}0.981 \\
(1.43)\end{array}$ & $\begin{array}{l}5.592 \\
(0.98)\end{array}$ & $\begin{array}{l}1.319 \\
(1.14)\end{array}$ & $\begin{array}{l}0.264 \\
(0.21)\end{array}$ & $\begin{array}{l}1.724 \\
(0.93)\end{array}$ & $\begin{array}{l}0.350 \\
(0.17)\end{array}$ & $\begin{array}{l}2.393 \\
(1.49)\end{array}$ \\
\hline$A C_{i, t}$ & $\begin{array}{c}0.206 * * * \\
(5.23)\end{array}$ & $\begin{array}{c}2.458 * * * \\
(7.86)\end{array}$ & $\begin{array}{c}1.033 * * * \\
(15.37)\end{array}$ & $\begin{array}{c}0.386 * * * \\
(5.65)\end{array}$ & $\begin{array}{c}0.594 * * * \\
(5.73)\end{array}$ & $\begin{array}{c}0.350 * * * \\
(3.25)\end{array}$ & $\begin{array}{c}0.219 * * \\
(2.51)\end{array}$ \\
\hline$S O E_{i, t}$ & $\begin{array}{c}0.532 * * * \\
(7.00)\end{array}$ & $\begin{array}{c}2.745 * * * \\
(4.66)\end{array}$ & $\begin{array}{l}0.088 \\
(0.68)\end{array}$ & $\begin{array}{c}0.802 * * * \\
(6.17)\end{array}$ & $\begin{array}{c}0.799 * * * \\
(4.02)\end{array}$ & $\begin{array}{c}1.284 * * * \\
(6.53)\end{array}$ & $\begin{array}{c}-0.300 * \\
(-1.71)\end{array}$ \\
\hline$T O P 1_{i, t}$ & $\begin{array}{c}-0.021 * * * \\
(-2.71)\end{array}$ & $\begin{array}{c}-0.134 * * \\
(-2.19)\end{array}$ & $\begin{array}{c}-0.027 * * \\
(-2.10)\end{array}$ & $\begin{array}{c}-0.035^{* *} \\
(-2.46)\end{array}$ & $\begin{array}{l}-0.006 \\
(-0.30)\end{array}$ & $\begin{array}{c}-0.048 * * \\
(-2.13)\end{array}$ & $\begin{array}{l}-0.014 \\
(-0.81)\end{array}$ \\
\hline$I O_{i, t}$ & $\begin{array}{l}0.186 \\
(1.10)\end{array}$ & $\begin{array}{l}2.472 \\
(1.64)\end{array}$ & $\begin{array}{c}1.134 * * * \\
(3.46)\end{array}$ & $\begin{array}{l}0.141 \\
(0.41)\end{array}$ & $\begin{array}{l}0.509 \\
(1.02)\end{array}$ & $\begin{array}{c}-1.322 * * * \\
(-2.60)\end{array}$ & $\begin{array}{c}1.744 * * * \\
(4.44)\end{array}$ \\
\hline$M O_{i, t}$ & $\begin{array}{c}3.876^{* * *} \\
(3.38)\end{array}$ & $\begin{array}{l}4.439 \\
(1.61)\end{array}$ & $\begin{array}{c}4.189 * * * \\
(5.08)\end{array}$ & $\begin{array}{c}1.259 * * \\
(2.06)\end{array}$ & $\begin{array}{c}3.207 * * * \\
(3.70)\end{array}$ & $\begin{array}{c}3.198 * * * \\
(4.05)\end{array}$ & $\begin{array}{l}0.643 \\
(0.62)\end{array}$ \\
\hline$H H 5_{i, t}$ & $\begin{array}{l}-0.382 \\
(-0.53)\end{array}$ & $\begin{array}{c}-24.646 * * * \\
(-4.22)\end{array}$ & $\begin{array}{c}-6.785 * * * \\
(-5.53)\end{array}$ & $\begin{array}{c}-6.692 * * * \\
(-5.27)\end{array}$ & $\begin{array}{c}-3.675 * \\
(-1.85)\end{array}$ & $\begin{array}{c}5.305^{* *} \\
(2.50)\end{array}$ & $\begin{array}{c}-16.263 * * * \\
(-10.23)\end{array}$ \\
\hline Duality $_{i, t}$ & $\begin{array}{c}1.187 * * \\
(2.37)\end{array}$ & $\begin{array}{c}9.208 * * \\
(2.56)\end{array}$ & $\begin{array}{c}4.246 * * * \\
(3.95)\end{array}$ & $\begin{array}{c}2.693 * * * \\
(2.74)\end{array}$ & $\begin{array}{l}0.342 \\
(0.14)\end{array}$ & $\begin{array}{c}3.855 * * * \\
(2.79)\end{array}$ & $\begin{array}{l}-0.491 \\
(-0.25)\end{array}$ \\
\hline$B$ Size $_{i, t}$ & $\begin{array}{l}0.100 \\
(0.99)\end{array}$ & $\begin{array}{l}0.343 \\
(0.46)\end{array}$ & $\begin{array}{l}-0.078 \\
(-0.44)\end{array}$ & $\begin{array}{l}-0.032 \\
(-0.19)\end{array}$ & $\begin{array}{l}0.206 \\
(0.82)\end{array}$ & $\begin{array}{l}0.067 \\
(0.27)\end{array}$ & $\begin{array}{l}0.143 \\
(0.66)\end{array}$ \\
\hline BIndep $_{i, t}$ & $\begin{array}{c}0.570 * * * \\
(2.74)\end{array}$ & $\begin{array}{c}3.494 * * \\
(2.05)\end{array}$ & $\begin{array}{c}1.021 * * * \\
(2.88)\end{array}$ & $\begin{array}{l}0.433 \\
(1.12)\end{array}$ & $\begin{array}{c}1.101 * * \\
(2.02)\end{array}$ & $\begin{array}{l}1.111^{*} \\
(1.85)\end{array}$ & $\begin{array}{l}-0.510 \\
(-1.07)\end{array}$ \\
\hline Constant & $\begin{array}{c}-3.907 * * * \\
(-6.27) \\
\end{array}$ & $\begin{array}{l}8.291 \\
(1.55) \\
\end{array}$ & $\begin{array}{c}3.606 * * * \\
(3.30) \\
\end{array}$ & $\begin{array}{l}1.847 \\
(1.54) \\
\end{array}$ & $\begin{array}{l}-0.162 \\
(-0.08) \\
\end{array}$ & $\begin{array}{l}0.036 \\
(0.02) \\
\end{array}$ & $\begin{array}{c}4.437 * * * \\
(2.96)\end{array}$ \\
\hline Year FE & Yes & Yes & Yes & Yes & Yes & Yes & Yes \\
\hline Industry FE & Yes & Yes & Yes & Yes & Yes & Yes & Yes \\
\hline \# of obs & 7,557 & 10,242 & 10,242 & 10,242 & 10,242 & 10,242 & 10,242 \\
\hline$A d j-R^{2}$ & & 0.319 & 0.620 & 0.240 & 0.224 & 0.215 & 0.144 \\
\hline Pseudo R2 & 0.182 & & & & & & \\
\hline $\begin{array}{l}\text { F-statistics } \\
\text { Wald Chi2 }\end{array}$ & 896.364 & 116.187 & 218.405 & 86.666 & 47.116 & 69.666 & 31.240 \\
\hline
\end{tabular}


Table 5 Robustness test: omitted variables

In this table, we use the change in firms' CSR scores as dependent variables and include firm fixed effects in regressions to address the concern that the negative relationship between institutional investor inattention and CSR engagement shown in Table 3 is driven by omitted variables. $d$. Score $i, t, d$. $M_{i, t}, d$. $C_{i, t}, d . T_{i, t,}$ and $d . I_{i, t}$ are the change in total RKS CSR scores, macrocosm scores (M), content scores (C), technique scores (T) and industry scores (I), respectively. For the convenience of interpretation, InAtti,t is standardized to have zero mean and unit variance in all regressions. In addition to firm fixed effects, year fixed effects are also included in all regressions. The t-statistics in parentheses are based on robust standard errors. *, **, and $* * *$ denote significance levels of $10 \%, 5 \%$, and $1 \%$, respectively.

\begin{tabular}{|c|c|c|c|c|c|}
\hline & $\begin{array}{c}(1) \\
\text { d. }^{\text {Score }}{ }_{i, t}\end{array}$ & $\begin{array}{c}(2) \\
d . M_{i, t}\end{array}$ & $\begin{array}{c}(3) \\
d . C_{i, t} \\
\end{array}$ & $\begin{array}{c}(4) \\
d . T_{i, t}\end{array}$ & $\begin{array}{c}(5) \\
d . I_{i, t}\end{array}$ \\
\hline $\operatorname{InAtt_{i,t}}$ & $\begin{array}{c}-0.081 * * \\
(-2.27)\end{array}$ & $\begin{array}{c}-0.012 * * \\
(-2.41)\end{array}$ & $\begin{array}{c}-0.059 * * \\
(-2.38)\end{array}$ & $\begin{array}{l}0.000 \\
(0.02)\end{array}$ & $\begin{array}{l}-0.010 \\
(-0.94)\end{array}$ \\
\hline Size $_{i, t}$ & $\begin{array}{c}0.194 * \\
(1.92)\end{array}$ & $\begin{array}{c}0.063^{*} \\
(1.83)\end{array}$ & $\begin{array}{l}-0.006 \\
(-0.14)\end{array}$ & $\begin{array}{c}0.075 * * * \\
(5.17)\end{array}$ & $\begin{array}{c}0.064 * * * \\
(4.07)\end{array}$ \\
\hline$B M_{i, t}$ & $\begin{array}{c}-0.331 * * * \\
(-4.38)\end{array}$ & $\begin{array}{l}0.030 \\
(1.10)\end{array}$ & $\begin{array}{c}-0.069 * * \\
(-1.99)\end{array}$ & $\begin{array}{c}-0.045^{* * *} \\
(-3.78)\end{array}$ & $\begin{array}{l}0.013 \\
(0.96)\end{array}$ \\
\hline$R O A_{i, t}$ & $\begin{array}{l}1.430 \\
(0.82)\end{array}$ & $\begin{array}{c}1.065^{*} \\
(1.81)\end{array}$ & $\begin{array}{l}0.380 \\
(0.50)\end{array}$ & $\begin{array}{c}-0.499 * \\
(-1.95)\end{array}$ & $\begin{array}{l}0.253 \\
(1.02)\end{array}$ \\
\hline$L e v_{i, t}$ & $\begin{array}{c}1.420 * * * \\
(3.08)\end{array}$ & $\begin{array}{l}0.044 \\
(0.29)\end{array}$ & $\begin{array}{l}0.226 \\
(1.23)\end{array}$ & $\begin{array}{l}0.099 \\
(1.54)\end{array}$ & $\begin{array}{l}0.064 \\
(0.96)\end{array}$ \\
\hline Capex $_{i, t}$ & $\begin{array}{l}1.162 \\
(0.67)\end{array}$ & $\begin{array}{l}0.924 \\
(1.64)\end{array}$ & $\begin{array}{l}0.290 \\
(0.42)\end{array}$ & $\begin{array}{l}0.208 \\
(0.86)\end{array}$ & $\begin{array}{l}0.008 \\
(0.03)\end{array}$ \\
\hline$A C_{i, t}$ & $\begin{array}{c}0.556^{* * * *} \\
(6.49)\end{array}$ & $\begin{array}{c}0.083 * * * \\
(2.99)\end{array}$ & $\begin{array}{c}0.088 * * \\
(2.56)\end{array}$ & $\begin{array}{l}-0.005 \\
(-0.46)\end{array}$ & $\begin{array}{l}0.018 \\
(1.45)\end{array}$ \\
\hline$S O E_{i, t}$ & $\begin{array}{c}0.640 * * * \\
(3.97)\end{array}$ & $\begin{array}{c}0.167 * * * \\
(3.10)\end{array}$ & $\begin{array}{l}0.001 \\
(0.02)\end{array}$ & $\begin{array}{l}0.025 \\
(1.10)\end{array}$ & $\begin{array}{c}0.053 * * \\
(2.28)\end{array}$ \\
\hline$T O P 1_{i, t}$ & $\begin{array}{l}-0.015 \\
(-0.83)\end{array}$ & $\begin{array}{l}-0.002 \\
(-0.30)\end{array}$ & $\begin{array}{l}0.001 \\
(0.09)\end{array}$ & $\begin{array}{l}0.002 \\
(0.63)\end{array}$ & $\begin{array}{c}-0.006 * * \\
(-1.97)\end{array}$ \\
\hline$I O_{i, t}$ & $\begin{array}{c}1.419 * * * \\
(4.15)\end{array}$ & $\begin{array}{c}0.481 * * * \\
(4.06)\end{array}$ & $\begin{array}{c}0.292 * \\
(1.92)\end{array}$ & $\begin{array}{c}0.246^{* * * *} \\
(4.74)\end{array}$ & $\begin{array}{c}0.115^{*} \\
(1.96)\end{array}$ \\
\hline$M O_{i, t}$ & $\begin{array}{l}1.665 \\
(1.30)\end{array}$ & $\begin{array}{l}0.458 \\
(1.01)\end{array}$ & $\begin{array}{l}-0.185 \\
(-0.39)\end{array}$ & $\begin{array}{l}0.080 \\
(0.46)\end{array}$ & $\begin{array}{l}-0.019 \\
(-0.13)\end{array}$ \\
\hline$H H 5_{i, t}$ & $\begin{array}{l}2.292 \\
(1.26)\end{array}$ & $\begin{array}{l}0.248 \\
(0.43)\end{array}$ & $\begin{array}{l}-0.514 \\
(-0.77)\end{array}$ & $\begin{array}{l}-0.060 \\
(-0.25)\end{array}$ & $\begin{array}{l}0.110 \\
(0.45)\end{array}$ \\
\hline Duality $_{i, t}$ & $\begin{array}{l}3.487 \\
(1.56)\end{array}$ & $\begin{array}{l}0.702 \\
(0.93)\end{array}$ & $\begin{array}{l}0.370 \\
(0.41)\end{array}$ & $\begin{array}{l}-0.130 \\
(-0.40)\end{array}$ & $\begin{array}{c}0.690 * * \\
(1.97)\end{array}$ \\
\hline$B S i z e_{i, t}$ & $\begin{array}{l}0.155 \\
(0.70)\end{array}$ & $\begin{array}{l}0.068 \\
(0.89)\end{array}$ & $\begin{array}{l}0.062 \\
(0.70)\end{array}$ & $\begin{array}{l}0.014 \\
(0.43)\end{array}$ & $\begin{array}{l}-0.034 \\
(-1.09)\end{array}$ \\
\hline BIndep $_{i, t}$ & $\begin{array}{l}0.740 \\
(1.57)\end{array}$ & $\begin{array}{l}0.245 \\
(1.52)\end{array}$ & $\begin{array}{l}0.210 \\
(1.09)\end{array}$ & $\begin{array}{l}-0.006 \\
(-0.09)\end{array}$ & $\begin{array}{c}0.157 * * \\
(2.15)\end{array}$ \\
\hline Constant & $\begin{array}{c}-2.556^{*} \\
(-1.71) \\
\end{array}$ & $\begin{array}{l}-0.815 \\
(-1.63) \\
\end{array}$ & $\begin{array}{l}-0.627 \\
(-1.03) \\
\end{array}$ & $\begin{array}{l}-0.113 \\
(-0.54) \\
\end{array}$ & $\begin{array}{c}-0.392 * \\
(-1.68) \\
\end{array}$ \\
\hline Firm FE & Yes & Yes & Yes & Yes & Yes \\
\hline Year FE & Yes & Yes & Yes & Yes & Yes \\
\hline \# of obs & 9,774 & 8,024 & 8,024 & 8,024 & 6,889 \\
\hline$A d j-R^{2}$ & 0.053 & 0.046 & 0.026 & 0.054 & 0.058 \\
\hline$F$-statistics & 11.092 & 6.186 & 4.623 & 5.452 & 5.126 \\
\hline
\end{tabular}


Table 6 Robustness test: lagged institutional investor inattention proxies

In this table, we regress CSR proxies on institutional investor inattention proxies that are lagged for one or two quarters. In Panel A, InAttit, is the aggregation of firm $i$ 's quarterly institutional investor inattention proxy in quarter 4 of year $t-1$, and those in quarters 1,2 and 3 of year $t$. In Panel $\mathrm{B}$, InAttit. $t_{i, t}^{q_{2}}$ is the aggregation of firm $i$ 's quarterly institutional investor inattention proxies in quarters 3 and 4 of year $t$ - 1 , and those in quarters 1 and 2 of year $t$. All other variables are defined in the appendix. For brevity, we omit results on control variables. InAtti,t and InAtti,t $t_{i, t}^{q 2}$ are standardized to have zero mean and unit variance in all regressions. Year and industry fixed effects are included in all regressions. The t-statistics in parentheses are based on robust standard errors. *, **, and *** denote significance levels of $10 \%, 5 \%$, and $1 \%$, respectively.

\begin{tabular}{|c|c|c|c|c|c|}
\hline \multicolumn{6}{|c|}{ Panel A One-quarter-lagged inattention proxies } \\
\hline & (1) & (2) & (3) & (4) & (5) \\
\hline & Score $_{i, t}$ & $M_{i, t}$ & $C_{i, t}$ & $T_{i, t}$ & $I_{i, t}$ \\
\hline \multirow{2}{*}{$\operatorname{In} A t t_{i, t}^{q 1}$} & $-0.580 * *$ & $-0.219 * *$ & $-0.133 *$ & -0.045 & $-0.082 * * *$ \\
\hline & $(-2.16)$ & $(-2.38)$ & $(-1.92)$ & $(-0.89)$ & $(-4.01)$ \\
\hline Year FE & Yes & Yes & Yes & Yes & Yes \\
\hline Industry FE & Yes & Yes & Yes & Yes & Yes \\
\hline \# of obs & 11,241 & 9,784 & 9,784 & 9,784 & 8,008 \\
\hline$A d j-R^{2}$ & 0.325 & 0.311 & 0.309 & 0.334 & 0.329 \\
\hline$F$-statistics & 211.457 & 205.014 & 212.479 & 202.565 & 111.246 \\
\hline
\end{tabular}

\begin{tabular}{lccccc}
\hline \multicolumn{1}{l}{ Panel B Two-quarter-lagged inattention proxies } & & & \\
\hline & $(1)$ & $(2)$ & $(3)$ & $(4)$ & $(5)$ \\
& Score $_{i, t}$ & $M_{i, t}$ & $C_{i, t}$ & $T_{i, t}$ & $I_{i, t}$ \\
\hline \multirow{2}{*}{ InAtt $_{i, t}^{q 2}$} & $-0.576^{* *}$ & $-0.295^{* * *}$ & $-0.101^{*}$ & -0.055 & $-0.072^{* * *}$ \\
& $(-2.09)$ & $(-2.77)$ & $(-1.79)$ & $(-1.22)$ & $(-3.69)$ \\
\hline Year FE & Yes & Yes & Yes & Yes & Yes \\
Industry FE & Yes & Yes & Yes & Yes & Yes \\
\# of obs & 10,157 & 9,141 & 9,141 & 9,141 & 7,848 \\
Adj-R2 & 0.296 & 0.318 & 0.305 & 0.289 & 0.344 \\
F-statistics & 205.221 & 197.154 & 211.326 & 208.547 & 121.875 \\
\hline
\end{tabular}


Table 7 Robustness test: the impact of institutional investor inattention on site visits

In this table, we study the impact of institutional investor inattention on site visits. DVisit $t_{i, t}$ equals 1 if firm $i$ is visited by institutional investors at least once in year $t$ and equals 0 otherwise. $N V i s i t_{i, t}$ is the log of 1 plus the number of times firm $i$ is visited by institutional investors in year $t$. DManu $u_{i, t}$ equals 1 if firm $\mathrm{i}$ is in the manufacturing industry and equals 0 otherwise. DRate $e_{i, t}$ equals 1 if the information disclosure quality of firm $i$ is relatively poor and hence is rated as C or D by the SZSE and equals 0 otherwise. Ret $_{i, t}$ is the market adjusted stock return of firm $i$ in year $t$. Age $e_{i, t}$ is the natural $\operatorname{logarithm}$ of years for which firm $i$ has been listing in SZSE. MShare $i, t$ is the market share of firm $i$ in year $t$. NFirms is the natural logarithm of the total number of listed firms in the city where firm $i$ is headquartered, while GDPGrowth $_{i, t}$ is the GDP growth of the city where firm $i$ is headquartered. For the convenience of interpretation, $\operatorname{InAtt}_{i, t}$ is standardized to have zero mean and unit variance in all regressions. All variables are defined in the appendix. Year and industry fixed effects are included in all regressions. The z-statistics in parentheses of column (1) and t-statistics in parentheses of column (2) are based on robust standard errors. *,**, and $* * *$ denote significance levels of $10 \%, 5 \%$, and $1 \%$, respectively.

\begin{tabular}{|c|c|c|}
\hline & (1) DVisit & (2) NVisit ${ }_{i, t}$ \\
\hline $\operatorname{InAtt}_{i, t}$ & $\begin{array}{c}-0.125 * * \\
(-2.29)\end{array}$ & $\begin{array}{c}-0.036^{* *} \\
(-1.98)\end{array}$ \\
\hline $\operatorname{DManu}_{i, t}$ & $\begin{array}{c}0.107 * * \\
(2.41)\end{array}$ & $\begin{array}{c}0.071 * * \\
(2.32)\end{array}$ \\
\hline DRate $_{i, t}$ & $\begin{array}{c}0.197 * * * \\
(4.13)\end{array}$ & $\begin{array}{c}0.099 * * * \\
(3.86)\end{array}$ \\
\hline $\operatorname{Ret}_{i, t}$ & $\begin{array}{c}-0.144 * * * \\
(-4.01)\end{array}$ & $\begin{array}{c}-0.025^{* *} \\
(-2.33)\end{array}$ \\
\hline$I O_{i, t}$ & $\begin{array}{l}0.044 \\
(0.44)\end{array}$ & $\begin{array}{l}0.021 \\
(0.25)\end{array}$ \\
\hline$A C_{i, t}$ & $\begin{array}{c}0.047 * * \\
(2.53)\end{array}$ & $\begin{array}{c}0.025^{*} \\
(1.80)\end{array}$ \\
\hline$B M_{i, t}$ & $\begin{array}{l}0.010 \\
(0.84)\end{array}$ & $\begin{array}{l}-0.006 \\
(-0.84)\end{array}$ \\
\hline $\operatorname{Size}_{i, t}$ & $\begin{array}{c}0.187 * * * \\
(4.25)\end{array}$ & $\begin{array}{c}0.075^{* * *} * \\
(3.19)\end{array}$ \\
\hline$R O A_{i, t}$ & $\begin{array}{l}0.039 \\
(0.11)\end{array}$ & $\begin{array}{l}0.011 \\
(0.63)\end{array}$ \\
\hline$L e v_{i, t}$ & $\begin{array}{l}-0.097 \\
(-1.05)\end{array}$ & $\begin{array}{c}0.005 \\
(0.25)\end{array}$ \\
\hline$A g e_{i, t}$ & $\begin{array}{l}0.021 \\
(0.82)\end{array}$ & $\begin{array}{c}-0.011 * \\
(-1.79)\end{array}$ \\
\hline$S O E_{i, t}$ & $\begin{array}{c}-0.045^{*} \\
(-1.72)\end{array}$ & $\begin{array}{l}-0.025 \\
(-1.54)\end{array}$ \\
\hline MShare $_{i, t-1}$ & $\begin{array}{c}0.219 * * * \\
(2.63)\end{array}$ & $\begin{array}{c}0.107 * * \\
(2.36)\end{array}$ \\
\hline NFirms $_{i, t}$ & $\begin{array}{c}0.028^{*} \\
(1.69)\end{array}$ & $\begin{array}{c}0.012 * * \\
(2.03)\end{array}$ \\
\hline GDPGrowth $_{i, t}$ & $\begin{array}{c}1.413 * * * \\
(6.44)\end{array}$ & $\begin{array}{c}0.712 * * * \\
(3.46)\end{array}$ \\
\hline Constant & $\begin{array}{c}0.799 * * * \\
(5.61)\end{array}$ & $\begin{array}{c}0.344 * \\
(1.83)\end{array}$ \\
\hline Year FE & Yes & Yes \\
\hline Industry FE & Yes & Yes \\
\hline \# of obs & 5,628 & 5,628 \\
\hline$A d j-R^{2}$ & & 0.196 \\
\hline Pseudo $R^{2}$ & 0.115 & \\
\hline $\begin{array}{l}F \text {-statistics } \\
L R \text { chi }^{2}\end{array}$ & 754.622 & 34.552 \\
\hline
\end{tabular}


Table 8 Sub-sample analyses by agency cost and managerial ownership

In this table, we investigate the impact of agency costs and managerial ownership on the relationship between institutional investor inattention and CSR engagement. The observations used in columns (1) and (2) are from firms with high agency costs and low agency costs, respectively. Following Ang et al. (2000), agency costs are measured by the expense ratio, which is the operating expense scaled by annual sales. A firm is considered to have high agency costs if its expense ratio is above the sample median in year $t$ and otherwise is considered to have low agency costs. The observations used in columns (3) and (4) are from firms with high managerial ownership and low managerial ownership, respectively. A firm is considered to have managerial ownership if its managerial ownership is above the sample median in year $t$ and otherwise is considered to have low managerial ownership. For the convenience of interpretation, InAtt $t_{i, t}$ is standardized to have zero mean and unit variance in all regressions. Year and industry fixed effects are included in all regressions. The t-statistics in parentheses are based on robust standard errors. $*, * *$, and $* * *$ denote significance levels of $10 \%, 5 \%$, and $1 \%$, respectively.

\begin{tabular}{|c|c|c|c|c|}
\hline \multirow{2}{*}{ Dep var $=$ Score $_{i, t}$} & \multicolumn{2}{|c|}{ Panel A Agency costs } & \multicolumn{2}{|c|}{ Panel B Managerial ownership } \\
\hline & (1) High & (2) Low & (3) High & (4) Low \\
\hline \multirow[t]{2}{*}{$\operatorname{InAtt}_{i, t}$} & $-0.691 * *$ & -0.257 & 0.094 & $-0.918 * *$ \\
\hline & $(-2.01)$ & $(-0.68)$ & $(0.69)$ & $(-2.31)$ \\
\hline \multirow[t]{2}{*}{$S_{i z} e_{i, t}$} & $7.689 * * *$ & $9.036 * * *$ & $7.403 * * *$ & $9.123 * * *$ \\
\hline & $(17.54)$ & $(19.16)$ & $(15.56)$ & $(20.37)$ \\
\hline \multirow[t]{2}{*}{$B M_{i, t}$} & $2.921 * * *$ & $4.470 * * *$ & $4.061 * * *$ & $3.702 * * *$ \\
\hline & $(7.54)$ & $(12.28)$ & $(10.45)$ & $(9.99)$ \\
\hline \multirow[t]{2}{*}{$R O A_{i, t}$} & $-26.387 * * *$ & -11.845 & $-21.770 * * *$ & -14.136 \\
\hline & $(-2.99)$ & $(-1.33)$ & $(-2.82)$ & $(-1.30)$ \\
\hline \multirow[t]{2}{*}{$L e v_{i, t}$} & -1.117 & $-12.407 * * *$ & -3.376 & $-11.626 * * *$ \\
\hline & $(-0.51)$ & $(-5.72)$ & $(-1.60)$ & $(-5.01)$ \\
\hline \multirow[t]{2}{*}{ Capex $_{i, t}$} & $26.559 * * *$ & -4.845 & 11.727 & 9.526 \\
\hline & $(3.79)$ & $(-0.64)$ & $(1.65)$ & $(1.24)$ \\
\hline \multirow{2}{*}{$A C_{i, t}$} & $1.564 * * *$ & $1.570 * * *$ & $1.932 * * *$ & $1.062 * *$ \\
\hline & (3.76) & (3.68) & (4.79) & (2.39) \\
\hline \multirow{2}{*}{$S O E_{i, t}$} & $5.515 * * *$ & $3.929 * * *$ & $3.525 * * *$ & $5.637 * * *$ \\
\hline & (7.07) & (4.38) & (4.59) & $(6.43)$ \\
\hline \multirow{2}{*}{$T O P 1_{i, t}$} & $-0.218 * *$ & $-0.611 * * *$ & $-0.194 * *$ & $-0.538 * * *$ \\
\hline & $(-2.48)$ & $(-7.27)$ & $(-2.21)$ & $(-6.56)$ \\
\hline \multirow[t]{2}{*}{$I O_{i, t}$} & $5.334 * *$ & $4.897 * * *$ & $6.061 * * *$ & $4.934 * *$ \\
\hline & $(2.48)$ & (2.63) & $(2.96)$ & $(2.50)$ \\
\hline \multirow[t]{2}{*}{$M O_{i, t}$} & $6.040 *$ & 0.678 & -1.532 & $8.215 * * *$ \\
\hline & $(1.84)$ & (1.63) & $(-0.45)$ & $(3.42)$ \\
\hline \multirow[t]{2}{*}{$H H 5_{i, t}$} & 10.250 & -7.374 & -6.681 & 3.028 \\
\hline & (1.37) & $(-1.00)$ & $(-0.84)$ & $(0.41)$ \\
\hline \multirow[t]{2}{*}{ Duality $_{i, t}$} & $44.188 * * *$ & $71.382 * * *$ & $28.037 * *$ & $70.762 * * *$ \\
\hline & (3.71) & (7.18) & $(2.52)$ & (7.02) \\
\hline \multirow[t]{2}{*}{$B$ Size $e_{i, t}$} & 0.103 & 1.909 & 1.447 & -0.224 \\
\hline & $(0.11)$ & (1.64) & (1.53) & $(-0.19)$ \\
\hline \multirow[t]{2}{*}{ BIndep $_{i, t}$} & $10.041 * * *$ & $4.337 *$ & $10.095 * * *$ & 1.732 \\
\hline & (4.30) & $(1.88)$ & $(4.21)$ & $(0.78)$ \\
\hline \multirow[t]{2}{*}{ Constant } & $-39.518 * * *$ & -4.488 & $-32.281 * * *$ & -5.460 \\
\hline & $(-5.61)$ & $(-0.65)$ & $(-4.61)$ & $(-0.79)$ \\
\hline Year FE & Yes & Yes & Yes & Yes \\
\hline Industry FE & Yes & Yes & Yes & Yes \\
\hline \# of obs & 6,278 & 6,278 & 6,278 & 6,278 \\
\hline$A d j-R^{2}$ & 0.329 & 0.374 & 0.333 & 0.357 \\
\hline F-statistics & 110.621 & 123.532 & 129.918 & 103.472 \\
\hline
\end{tabular}


Table 9 Sub-sample analyses by internal control quality and analyst coverage

In this table, we investigate the impact of internal control quality and analyst coverage on the relationship between institutional investor inattention and CSR engagement. Observations used in column (1) are from firms with relatively high internal control quality, while observations used in column (2) are from firms with relatively low internal control quality. We measure firms' internal control quality with their DIB internal control index values provided by the DIB internal control and risk management firm in China. A firm-year observation is classified into the sub-sample of high (low) internal control quality if its DIB internal control index value is above (below) the sample median in year $t$. Observations used in column (3) are from firms with high analyst coverage, while observations used in column (4) are from firms with low analyst coverage. A firm-year observation is classified into the sub-sample of high (low) analyst coverage if its analyst coverage is above (below) the sample median in year $t$. For the convenience of interpretation, InAtt $t_{i, t}$ is standardized to have zero mean and unit variance in all regressions. Year and industry fixed effects are included in all regressions. The t-statistics in parentheses are based on robust standard errors. *, **, and *** denote significance levels of $10 \%, 5 \%$, and $1 \%$, respectively.

\begin{tabular}{|c|c|c|c|c|}
\hline \multirow{2}{*}{ Dep var $=$ Score $_{i, t}$} & \multicolumn{2}{|c|}{ Panel A Internal control quality } & \multicolumn{2}{|c|}{ Panel B Mandatory CSR disclosures } \\
\hline & (1) High & (2) Low & (3) High & (4) Low \\
\hline $\operatorname{InAtt}_{i, t}$ & $\begin{array}{l}0.035 \\
(0.08)\end{array}$ & $\begin{array}{c}-0.897 * * \\
(-2.48)\end{array}$ & $\begin{array}{l}-0.456 \\
(-1.24)\end{array}$ & $\begin{array}{c}-0.668^{*} \\
(-1.94)\end{array}$ \\
\hline$S_{i z} e_{i, t}$ & $\begin{array}{c}8.234 * * * \\
(18.00)\end{array}$ & $\begin{array}{c}3.477 * * * \\
(8.80)\end{array}$ & $\begin{array}{c}8.940 * * * \\
(20.99)\end{array}$ & $\begin{array}{c}8.074 * * * \\
(15.51)\end{array}$ \\
\hline$B M_{i, t}$ & $\begin{array}{c}2.989 * * * \\
(8.29)\end{array}$ & $\begin{array}{c}1.059 * * \\
(2.56)\end{array}$ & $\begin{array}{c}3.953 * * * \\
(10.97)\end{array}$ & $\begin{array}{c}3.432 * * * \\
(8.49)\end{array}$ \\
\hline$R O A_{i, t}$ & $\begin{array}{c}-41.662 * * * \\
(-3.76)\end{array}$ & $\begin{array}{c}-26.585 * * * * \\
(-4.27)\end{array}$ & $\begin{array}{c}-35.238 * * * \\
(-3.13)\end{array}$ & $\begin{array}{c}-19.180 * * \\
(-2.36)\end{array}$ \\
\hline$L e v_{i, t}$ & $\begin{array}{l}-0.013 \\
(-0.00)\end{array}$ & $\begin{array}{c}-4.074 * * \\
(-2.57)\end{array}$ & $\begin{array}{c}-9.236 * * * \\
(-3.78)\end{array}$ & $\begin{array}{c}-6.029 * * * \\
(-3.00)\end{array}$ \\
\hline Capex $_{i, t}$ & $\begin{array}{l}-2.925 \\
(-0.44)\end{array}$ & $\begin{array}{l}0.230 \\
(0.04)\end{array}$ & $\begin{array}{l}5.651 \\
(0.82)\end{array}$ & $\begin{array}{l}12.007 \\
(1.49)\end{array}$ \\
\hline$A C_{i, t}$ & $\begin{array}{l}0.004 \\
(0.01)\end{array}$ & $\begin{array}{l}0.398 \\
(1.31)\end{array}$ & $\begin{array}{c}1.380 * * * \\
(3.18)\end{array}$ & $\begin{array}{c}1.436 * * * \\
(3.36)\end{array}$ \\
\hline$S O E_{i, t}$ & $\begin{array}{c}2.052 * * \\
(2.14)\end{array}$ & $\begin{array}{c}2.010 * * * \\
(3.37)\end{array}$ & $\begin{array}{c}4.463 * * * \\
(5.22)\end{array}$ & $\begin{array}{c}4.331 * * * \\
(5.61)\end{array}$ \\
\hline$T O P 1_{i, t}$ & $\begin{array}{c}-0.519 * * * \\
(-6.69)\end{array}$ & $\begin{array}{l}-0.094 \\
(-1.35)\end{array}$ & $\begin{array}{c}-0.430 * * * \\
(-5.25)\end{array}$ & $\begin{array}{c}-0.303 * * * \\
(-3.41)\end{array}$ \\
\hline$I O_{i, t}$ & $\begin{array}{c}7.907 * * * \\
(5.10)\end{array}$ & $\begin{array}{l}2.445 \\
(1.41)\end{array}$ & $\begin{array}{c}5.261 * * * \\
(2.70)\end{array}$ & $\begin{array}{c}5.227 * * \\
(2.53)\end{array}$ \\
\hline$M O_{i, t}$ & $\begin{array}{c}10.495 * * \\
(2.41)\end{array}$ & $\begin{array}{l}0.160 \\
(0.06)\end{array}$ & $\begin{array}{l}-2.309 \\
(-0.62)\end{array}$ & $\begin{array}{c}17.156^{* * * *} \\
(3.05)\end{array}$ \\
\hline$H H 5_{i, t}$ & $\begin{array}{c}-36.782 * * * \\
(-4.21)\end{array}$ & $\begin{array}{l}-1.643 \\
(-0.30)\end{array}$ & $\begin{array}{c}-12.177 * \\
(-1.75)\end{array}$ & $\begin{array}{c}12.739 \\
(1.53)\end{array}$ \\
\hline Duality $_{i, t}$ & $\begin{array}{c}62.847 * * * \\
(6.76)\end{array}$ & $\begin{array}{l}12.380 \\
(1.39)\end{array}$ & $\begin{array}{c}58.065^{* * * *} \\
(5.88)\end{array}$ & $\begin{array}{c}42.662 * * * \\
(3.65)\end{array}$ \\
\hline$B S i z e_{i, t}$ & $\begin{array}{l}0.607 \\
(0.52)\end{array}$ & $\begin{array}{l}0.544 \\
(0.74)\end{array}$ & $\begin{array}{l}1.283 \\
(1.16)\end{array}$ & $\begin{array}{l}0.241 \\
(0.24)\end{array}$ \\
\hline BIndep $_{i, t}$ & $\begin{array}{l}1.089 \\
(0.55)\end{array}$ & $\begin{array}{c}7.157 * * * \\
(3.82)\end{array}$ & $\begin{array}{l}4.350^{*} \\
(1.94)\end{array}$ & $\begin{array}{c}8.428 * * * \\
(3.58)\end{array}$ \\
\hline Constant & $\begin{array}{c}28.227 * * * \\
(4.16) \\
\end{array}$ & $\begin{array}{c}-13.521 * * \\
(-2.16) \\
\end{array}$ & $\begin{array}{r}-10.861 \\
(-1.60) \\
\end{array}$ & $\begin{array}{c}-27.250 * * * \\
(-3.78) \\
\end{array}$ \\
\hline Year FE & Yes & Yes & Yes & Yes \\
\hline Industry FE & Yes & Yes & Yes & Yes \\
\hline \# of obs & 6,278 & 6,278 & 6,278 & 6,278 \\
\hline$A d j-R^{2}$ & 0.421 & 0.076 & 0.388 & 0.276 \\
\hline F-statistics & 53.545 & 10.538 & 147.181 & 68.245 \\
\hline
\end{tabular}


Table 10 The impact of institution types

In this table, we classify institutional investors into ten types according to their institution types. We calculate the yearly inattention of each institutional investor with the model (1) and aggregate them at the institution-firm level ( $\left.\operatorname{InAttI}_{i, t}^{n}, \mathrm{n}=1,2, \ldots, 10\right)$. InAtt ${ }_{i, t}^{n}$ stands for the inattention of insurance companies, public mutual funds, the national social security fund, exchange-traded funds, overseas institutional investors, corporate annuity plans, banks, trust companies, brokerage firms, and private investment funds in columns (1) to (10), respectively. For the convenience of interpretation, InAttI $I_{i, t}^{n}$ is standardized to have zero mean and unit variance in all regressions. All variables are defined in the appendix. Year and industry fixed effects are included in all regressions. The t-statistics in parentheses are based on robust standard errors. $*, * *$, and $* * *$ denote significance levels of $10 \%, 5 \%$, and $1 \%$, respectively.

\begin{tabular}{|c|c|c|c|c|c|c|c|c|c|c|}
\hline Dep Var= & (1) & (2) & (3) & (4) & (5) & (6) & (7) & (8) & (9) & (10) \\
\hline Score $_{i, t}$ & $\begin{array}{l}\text { Insurance } \\
\text { companies }\end{array}$ & $\begin{array}{l}\text { Mutual } \\
\text { funds }\end{array}$ & $\begin{array}{l}\text { Social security } \\
\text { fund }\end{array}$ & ETF & Overseas & $\begin{array}{l}\text { Annuity } \\
\text { plans }\end{array}$ & Banks & $\begin{array}{c}\text { Trust } \\
\text { companies }\end{array}$ & $\begin{array}{l}\text { Brokerage } \\
\text { firms }\end{array}$ & $\begin{array}{l}\text { Private } \\
\text { funds }\end{array}$ \\
\hline $\operatorname{InAttI} I_{i, t}^{n}$ & $\begin{array}{c}-0.750 * * \\
(-2.17)\end{array}$ & $\begin{array}{c}-0.870 * \\
(-1.92)\end{array}$ & $\begin{array}{c}-0.170 * * * \\
(-4.71)\end{array}$ & $\begin{array}{l}0.083 \\
(0.22)\end{array}$ & $\begin{array}{l}-0.262 \\
(-1.30)\end{array}$ & $\begin{array}{l}-0.448 \\
(-1.37)\end{array}$ & $\begin{array}{l}-0.064 \\
(-0.31)\end{array}$ & $\begin{array}{l}-0.615 \\
(-1.04)\end{array}$ & $\begin{array}{l}0.019 \\
(0.15)\end{array}$ & $\begin{array}{l}0.131 \\
(1.41)\end{array}$ \\
\hline$S i z e_{i, t}$ & $\begin{array}{c}8.618 * * * \\
(27.34)\end{array}$ & $\begin{array}{c}8.629 * * * \\
(27.36)\end{array}$ & $\begin{array}{c}8.599 * * * \\
(27.23)\end{array}$ & $\begin{array}{c}8.622 * * * \\
(27.37)\end{array}$ & $\begin{array}{c}8.605 * * * \\
(27.29)\end{array}$ & $\begin{array}{c}8.517 * * * \\
(26.29)\end{array}$ & $\begin{array}{c}8.595 * * * \\
(27.18)\end{array}$ & $\begin{array}{c}8.625 * * * \\
(27.35)\end{array}$ & $\begin{array}{c}8.619 * * * \\
(27.32)\end{array}$ & $\begin{array}{c}8.622 * * * \\
(27.35)\end{array}$ \\
\hline$B M_{i, t}$ & $\begin{array}{c}3.859 * * * \\
(14.57)\end{array}$ & $\begin{array}{c}3.857 * * * \\
(14.56)\end{array}$ & $\begin{array}{c}3.866 * * * \\
(14.60)\end{array}$ & $\begin{array}{c}3.857 * * * \\
(14.57)\end{array}$ & $\begin{array}{c}3.856 * * * \\
(14.56)\end{array}$ & $\begin{array}{c}3.850 * * * \\
(14.54)\end{array}$ & $\begin{array}{c}3.848 * * * \\
(14.54)\end{array}$ & $\begin{array}{c}3.858 * * * \\
(14.57)\end{array}$ & $\begin{array}{c}3.859 * * * \\
(14.57)\end{array}$ & $\begin{array}{c}3.861 * * * \\
(14.58)\end{array}$ \\
\hline$R O A_{i, t}$ & $\begin{array}{c}-20.217 * * * \\
(-3.21)\end{array}$ & $\begin{array}{c}-20.342 * * * \\
(-3.23)\end{array}$ & $\begin{array}{c}-20.335 * * * \\
(-3.23)\end{array}$ & $\begin{array}{c}-20.242 * * * \\
(-3.22)\end{array}$ & $\begin{array}{c}-20.278 * * * \\
(-3.22)\end{array}$ & $\begin{array}{c}-19.974 * * * \\
(-3.17)\end{array}$ & $\begin{array}{c}-20.397 * * * \\
(-3.24)\end{array}$ & $\begin{array}{c}-20.301 * * * \\
(-3.23)\end{array}$ & $\begin{array}{c}-20.236 * * * \\
(-3.22)\end{array}$ & $\begin{array}{c}-20.222 * * * \\
(-3.21)\end{array}$ \\
\hline $\operatorname{Lev}_{i, t}$ & $\begin{array}{c}-7.398 * * * \\
(-4.79)\end{array}$ & $\begin{array}{c}-7.357 * * * \\
(-4.77)\end{array}$ & $\begin{array}{c}-7.476 * * * \\
(-4.85)\end{array}$ & $\begin{array}{c}-7.383 * * * \\
(-4.78)\end{array}$ & $\begin{array}{c}-7.354 * * * \\
(-4.76)\end{array}$ & $\begin{array}{c}-7.333 * * * \\
(-4.75)\end{array}$ & $\begin{array}{c}-7.341 * * * \\
(-4.76)\end{array}$ & $\begin{array}{c}-7.385 * * * \\
(-4.79)\end{array}$ & $\begin{array}{c}-7.385 * * * \\
(-4.79)\end{array}$ & $\begin{array}{c}-7.405 * * * \\
(-4.80)\end{array}$ \\
\hline Capex $_{i, t}$ & $\begin{array}{c}10.039 * \\
(1.91)\end{array}$ & $\begin{array}{c}9.925^{*} \\
(1.89)\end{array}$ & $\begin{array}{c}10.143^{*} \\
(1.93)\end{array}$ & $\begin{array}{c}10.040^{*} \\
(1.91)\end{array}$ & $\begin{array}{c}10.163^{*} \\
(1.94)\end{array}$ & $\begin{array}{c}10.133^{*} \\
(1.93)\end{array}$ & $\begin{array}{c}10.004 * \\
(1.91)\end{array}$ & $\begin{array}{c}9.949^{*} \\
(1.89)\end{array}$ & $\begin{array}{c}10.027^{*} \\
(1.91)\end{array}$ & $\begin{array}{c}9.978^{*} \\
(1.90)\end{array}$ \\
\hline$A C_{i, t}$ & $\begin{array}{c}1.352 * * * \\
(4.85)\end{array}$ & $\begin{array}{c}1.357 * * * \\
(4.87)\end{array}$ & $\begin{array}{c}1.375 * * * \\
(4.92)\end{array}$ & $\begin{array}{c}1.348 * * * \\
(4.84)\end{array}$ & $\begin{array}{c}1.355 * * * \\
(4.86)\end{array}$ & $\begin{array}{c}1.444 * * * \\
(4.99)\end{array}$ & $\begin{array}{c}1.389 * * * \\
(4.96)\end{array}$ & $\begin{array}{c}1.352 * * * \\
(4.85)\end{array}$ & $\begin{array}{c}1.349 * * * \\
(4.84)\end{array}$ & $\begin{array}{c}1.354 * * * \\
(4.86)\end{array}$ \\
\hline$S O E_{i, t}$ & $\begin{array}{c}4.454 * * * \\
(7.82)\end{array}$ & $\begin{array}{c}4.461 * * * \\
(7.84)\end{array}$ & $\begin{array}{c}4.480 * * * \\
(7.85)\end{array}$ & $\begin{array}{c}4.446 * * * \\
(7.81)\end{array}$ & $\begin{array}{c}4.458 * * * \\
(7.84)\end{array}$ & $\begin{array}{c}4.483 * * * \\
(7.86)\end{array}$ & $\begin{array}{c}4.471 * * * \\
(7.86)\end{array}$ & $\begin{array}{c}4.458 * * * \\
(7.83)\end{array}$ & $\begin{array}{c}4.452 * * * \\
(7.82)\end{array}$ & $\begin{array}{c}4.443 * * * \\
(7.81)\end{array}$ \\
\hline$T O P 1_{i, t}$ & $\begin{array}{c}-0.383 * * * \\
(-6.45)\end{array}$ & $\begin{array}{c}-0.383 * * * \\
(-6.44)\end{array}$ & $\begin{array}{c}-0.385^{* * * *} \\
(-6.48)\end{array}$ & $\begin{array}{c}-0.384 * * * \\
(-6.46)\end{array}$ & $\begin{array}{c}-0.383^{* * *} \\
(-6.45)\end{array}$ & $\begin{array}{c}-0.383 * * * \\
(-6.45)\end{array}$ & $\begin{array}{c}-0.385^{* * *} \\
(-6.48)\end{array}$ & $\begin{array}{c}-0.384 * * * \\
(-6.47)\end{array}$ & $\begin{array}{c}-0.383^{* * *} \\
(-6.45)\end{array}$ & $\begin{array}{c}-0.383 * * * \\
(-6.44)\end{array}$ \\
\hline$I O_{i, t}$ & $\begin{array}{c}4.994 * * * \\
(3.53)\end{array}$ & $\begin{array}{c}4.985 * * * \\
(3.52)\end{array}$ & $\begin{array}{c}5.033 * * * \\
(3.56)\end{array}$ & $\begin{array}{c}4.992 * * * \\
(3.53)\end{array}$ & $\begin{array}{c}4.983 * * * \\
(3.52)\end{array}$ & $\begin{array}{c}5.091 * * * \\
(3.59)\end{array}$ & $\begin{array}{c}5.051 * * * \\
(3.57)\end{array}$ & $\begin{array}{c}4.985 * * * \\
(3.52)\end{array}$ & $\begin{array}{c}4.992 * * * \\
(3.53)\end{array}$ & $\begin{array}{c}4.994 * * * \\
(3.53)\end{array}$ \\
\hline$M O_{i, t}$ & $\begin{array}{c}5.930^{* *} \\
(2.00)\end{array}$ & $\begin{array}{c}5.984 * * \\
(2.02)\end{array}$ & $\begin{array}{c}6.015^{* *} \\
(2.03)\end{array}$ & $\begin{array}{c}5.917 * * \\
(2.00)\end{array}$ & $\begin{array}{c}5.982 * * \\
(2.02)\end{array}$ & $\begin{array}{c}6.039 * * \\
(2.04)\end{array}$ & $\begin{array}{c}5.956^{* *} \\
(2.01)\end{array}$ & $\begin{array}{c}5.907 * * \\
(1.99)\end{array}$ & $\begin{array}{c}5.913^{* *} \\
(1.99)\end{array}$ & $\begin{array}{c}5.914 * * \\
(1.99)\end{array}$ \\
\hline$H H 5_{i, t}$ & $\begin{array}{l}-1.837 \\
(-0.34)\end{array}$ & $\begin{array}{l}-1.734 \\
(-0.33)\end{array}$ & $\begin{array}{l}-1.941 \\
(-0.36)\end{array}$ & $\begin{array}{l}-1.851 \\
(-0.35)\end{array}$ & $\begin{array}{l}-1.941 \\
(-0.36)\end{array}$ & $\begin{array}{l}-1.548 \\
(-0.29)\end{array}$ & $\begin{array}{l}-1.715 \\
(-0.32)\end{array}$ & $\begin{array}{l}-1.852 \\
(-0.35)\end{array}$ & $\begin{array}{l}-1.864 \\
(-0.35)\end{array}$ & $\begin{array}{l}-2.115 \\
(-0.40)\end{array}$ \\
\hline
\end{tabular}




\begin{tabular}{|c|c|c|c|c|c|c|c|c|c|c|}
\hline Duality $_{i, t}$ & $\begin{array}{c}53.087 * * * \\
(7.13)\end{array}$ & $\begin{array}{c}53.003 * * * \\
(7.13)\end{array}$ & $\begin{array}{c}53.235^{* * * *} \\
(7.16)\end{array}$ & $\begin{array}{c}53.151 * * * \\
(7.15)\end{array}$ & $\begin{array}{c}53.155^{* * *} \\
(7.15)\end{array}$ & $\begin{array}{c}52.969 * * * \\
(7.12)\end{array}$ & $\begin{array}{c}53.270 * * * \\
\quad(7.16)\end{array}$ & $\begin{array}{c}53.198 * * * \\
(7.15)\end{array}$ & $\begin{array}{c}53.112 * * * \\
\quad(7.14)\end{array}$ & $\begin{array}{c}53.062 * * * \\
(7.13)\end{array}$ \\
\hline$B_{\text {Size }} e_{i, t}$ & $\begin{array}{c}0.808 \\
(1.09)\end{array}$ & $\begin{array}{l}0.815 \\
(1.10)\end{array}$ & $\begin{array}{c}0.796 \\
(1.08)\end{array}$ & $\begin{array}{l}0.810 \\
(1.09)\end{array}$ & $\begin{array}{l}0.811 \\
(1.10)\end{array}$ & $\begin{array}{c}0.789 \\
(1.06)\end{array}$ & $\begin{array}{c}0.778 \\
(1.05)\end{array}$ & $\begin{array}{c}0.808 \\
(1.09)\end{array}$ & $\begin{array}{c}0.809 \\
(1.09)\end{array}$ & $\begin{array}{l}0.811 \\
(1.10)\end{array}$ \\
\hline BIndep $_{i, t}$ & $\begin{array}{c}6.496 * * * \\
(4.00)\end{array}$ & $\begin{array}{c}6.504 * * * \\
(4.01)\end{array}$ & $\begin{array}{c}6.460 * * * \\
(3.98)\end{array}$ & $\begin{array}{c}6.491 * * * \\
(4.00)\end{array}$ & $\begin{array}{c}6.545 * * * \\
(4.03)\end{array}$ & $\begin{array}{c}6.466 * * * \\
(3.99)\end{array}$ & $\begin{array}{c}6.419 * * * \\
(3.95)\end{array}$ & $\begin{array}{c}6.480 * * * \\
(3.99)\end{array}$ & $\begin{array}{c}6.501 * * * \\
(4.01)\end{array}$ & $\begin{array}{c}6.477 * * * \\
(3.99)\end{array}$ \\
\hline Constant & $\begin{array}{c}-20.351 * * * \\
(-4.14) \\
\end{array}$ & $\begin{array}{c}-20.044 * * * \\
(-4.07) \\
\end{array}$ & $\begin{array}{c}-20.287 * * * \\
(-4.13) \\
\end{array}$ & $\begin{array}{c}-20.332 * * * \\
(-4.13) \\
\end{array}$ & $\begin{array}{c}-20.514 * * * \\
(-4.17) \\
\end{array}$ & $\begin{array}{c}-20.400 * * * \\
(-4.15) \\
\end{array}$ & $\begin{array}{c}-20.225 * * * \\
(-4.11) \\
\end{array}$ & $\begin{array}{c}-20.278 * * * \\
(-4.12) \\
\end{array}$ & $\begin{array}{c}-20.354 * * * \\
(-4.14) \\
\end{array}$ & $\begin{array}{c}-20.262 * * * \\
(-4.12) \\
\end{array}$ \\
\hline Year FE & Yes & Yes & Yes & Yes & Yes & Yes & Yes & Yes & Yes & Yes \\
\hline Industry FE & Yes & Yes & Yes & Yes & Yes & Yes & Yes & Yes & Yes & Yes \\
\hline \# of obs & 12,556 & 12,556 & 12,556 & 12,556 & 12,556 & 12,556 & 12,556 & 12,556 & 12,556 & 12,556 \\
\hline $\operatorname{Adj}-R^{2}$ & 0.345 & 0.345 & 0.345 & 0.345 & 0.345 & 0.345 & 0.345 & 0.345 & 0.345 & 0.345 \\
\hline$F$-statistics & 214.264 & 215.255 & 214.524 & 214.508 & 214.224 & 214.417 & 215.370 & 215.953 & 214.300 & 214.399 \\
\hline
\end{tabular}


Table 11 The impact of institutional investors' trading styles

In this table, we investigate whether the impact of institutional investors is determined by their trading styles. Following Bushee (1998) and Bushee and Noe (2000), we classify institutional investors into dedicated institutional investors, transient institutional investors and quasi-indexers according to their portfolio concentration, portfolio turnover, and trading strategies. We construct proxies for the inattention of dedicated institutional investors, transient institutional investors and quasi-indexers and denote them as $\operatorname{InAttD} D_{i, t}, \operatorname{InAtt} T_{i, t}$ and $\operatorname{InAtt} Q_{i, t}$, respectively. For convenience of interpretation, $\operatorname{InAtt} D_{i, t}, \operatorname{InAtt} T_{i, t}$ and $\operatorname{InAtt} Q_{i, t}$ are standardized to have zero mean and unit variance in all regressions. All variables are defined in the appendix. Year and industry fixed effects are included in all regressions. The t-statistics in parentheses are based on robust standard errors. *, **, and $* * *$ denote significance levels of $10 \%, 5 \%$, and $1 \%$, respectively.

\begin{tabular}{|c|c|c|c|}
\hline Dep Var $=$ Score $_{i, t}$ & (1) & (2) & (3) \\
\hline $\operatorname{InAtt} D_{i, t}$ & $\begin{array}{c}-0.379 * * \\
(-1.96)\end{array}$ & & \\
\hline $\operatorname{InAtt} T_{i, t}$ & & $\begin{array}{l}-0.038 \\
(-0.12)\end{array}$ & \\
\hline $\operatorname{InAtt} Q_{i, t}$ & & & $\begin{array}{c}-0.515 * * \\
(-2.25)\end{array}$ \\
\hline$S i z e_{i, t}$ & $\begin{array}{c}8.554 * * * \\
(26.92)\end{array}$ & $\begin{array}{c}8.607 * * * \\
(26.14)\end{array}$ & $\begin{array}{c}8.616 * * * \\
(27.35)\end{array}$ \\
\hline$B M_{i, t}$ & $\begin{array}{c}3.833 * * * \\
(14.43)\end{array}$ & $\begin{array}{c}3.857 * * * \\
(14.56)\end{array}$ & $\begin{array}{c}3.866^{* * * *} \\
(14.60)\end{array}$ \\
\hline$R O A_{i, t}$ & $\begin{array}{c}-20.165^{* * * *} \\
(-3.20)\end{array}$ & $\begin{array}{c}-20.201 * * * \\
(-3.21)\end{array}$ & $\begin{array}{c}-19.943 * * * \\
(-3.17)\end{array}$ \\
\hline $\operatorname{Lev}_{i, t}$ & $\begin{array}{c}-7.318 * * * \\
(-4.74)\end{array}$ & $\begin{array}{c}-7.381 * * * \\
(-4.78)\end{array}$ & $\begin{array}{c}-7.409 * * * \\
(-4.80)\end{array}$ \\
\hline Capex $_{i, t}$ & $\begin{array}{c}10.003^{*} \\
(1.91)\end{array}$ & $\begin{array}{c}10.034 * \\
(1.91)\end{array}$ & $\begin{array}{c}9.986^{*} \\
(1.90)\end{array}$ \\
\hline$A C_{i, t}$ & $\begin{array}{c}1.415 * * * \\
(5.00)\end{array}$ & $\begin{array}{c}1.359 * * * \\
(4.64)\end{array}$ & $\begin{array}{c}1.342 * * * \\
(4.82)\end{array}$ \\
\hline$S O E_{i, t}$ & $\begin{array}{c}4.459 * * * \\
(7.84)\end{array}$ & $\begin{array}{c}4.459 * * * \\
(7.77)\end{array}$ & $\begin{array}{c}4.488 * * * \\
(7.88)\end{array}$ \\
\hline$T O P 1_{i, t}$ & $\begin{array}{c}-0.381 * * * \\
(-6.41)\end{array}$ & $\begin{array}{c}-0.383 * * * \\
(-6.45)\end{array}$ & $\begin{array}{c}-0.384 * * * \\
(-6.46)\end{array}$ \\
\hline$I O_{i, t}$ & $\begin{array}{c}5.040 * * * \\
(3.56)\end{array}$ & $\begin{array}{c}5.000 * * * \\
(3.53)\end{array}$ & $\begin{array}{c}4.987 * * * \\
(3.53)\end{array}$ \\
\hline$M O_{i, t}$ & $\begin{array}{c}5.749^{*} \\
(1.94)\end{array}$ & $\begin{array}{c}5.940 * * \\
(2.00)\end{array}$ & $\begin{array}{c}5.893^{* *} * \\
(1.99)\end{array}$ \\
\hline$H H 5_{i, t}$ & $\begin{array}{l}-1.912 \\
(-0.36)\end{array}$ & $\begin{array}{l}-1.837 \\
(-0.34)\end{array}$ & $\begin{array}{l}-1.779 \\
(-0.33)\end{array}$ \\
\hline Duality $_{i, t}$ & $\begin{array}{c}12.808 * * * \\
(7.10)\end{array}$ & $\begin{array}{c}13.096 * * * \\
(7.14)\end{array}$ & $\begin{array}{c}13.109 * * * \\
(7.15)\end{array}$ \\
\hline$B S i z e_{i, t}$ & $\begin{array}{l}0.812 \\
(1.10)\end{array}$ & $\begin{array}{l}0.808 \\
(1.09)\end{array}$ & $\begin{array}{l}0.804 \\
(1.09)\end{array}$ \\
\hline BIndep $_{i, t}$ & $\begin{array}{c}6.459 * * * \\
(3.98)\end{array}$ & $\begin{array}{c}6.499 * * * \\
(4.01)\end{array}$ & $\begin{array}{c}6.470 * * * \\
(3.99)\end{array}$ \\
\hline Constant & $\begin{array}{c}-20.299 * * * \\
(-4.13)\end{array}$ & $\begin{array}{c}-20.352 * * * \\
(-4.14)\end{array}$ & $\begin{array}{c}-20.298 * * * \\
(-4.13)\end{array}$ \\
\hline Year FE & Yes & Yes & Yes \\
\hline Industry FE & Yes & Yes & Yes \\
\hline \# of obs & 12,556 & 12,556 & 12,556 \\
\hline$A d j-R^{2}$ & 0.353 & 0.352 & 0.353 \\
\hline F-statistics & 211.701 & 211.208 & 210.988 \\
\hline
\end{tabular}

